\title{
Appropriate Growth Policy: A Unifying Framework
}

\section{Citation}

Aghion, Philippe, and Peter Howitt. 2006. Appropriate growth policy: A unifying framework. Journal of the European Economic Association 4(2-3): 269-314.

\section{Published Version}

doi:10.1162/jeea.2006.4.2-3.269

\section{Permanent link}

http://nrs.harvard.edu/urn-3:HUL.InstRepos:4554121

\section{Terms of Use}

This article was downloaded from Harvard University's DASH repository, and is made available under the terms and conditions applicable to Other Posted Material, as set forth at http:// nrs.harvard.edu/urn-3:HUL.InstRepos:dash.current.terms-of-use\#LAA

\section{Share Your Story}

The Harvard community has made this article openly available.

Please share how this access benefits you. Submit a story.

Accessibility 


\title{
JOSEPH SCHUMPETER LECTURE APPROPRIATE GROWTH POLICY: A UNIFYING FRAMEWORK
}

\author{
Philippe Aghion \\ Harvard University
}

\author{
Peter Howitt \\ Brown University
}

\begin{abstract}
In this lecture, we use Schumpeterian growth theory, where growth comes from qualityimproving innovations, to elaborate a theory of growth policy and to explain the growth gap between Europe and the US. Our theoretical apparatus systematizes the case-by-case approach to growth policy design. The emphasis is on three policy areas that are potentially relevant for growth in Europe, namely: competition and entry, education, and macropolicy. We argue that higher entry and exit (higher firm turnover) and increased emphasis on higher education are more growth-enhancing in countries that are closer to the technological frontier. We also argue that countercyclical budgetary policies are more growth-enhancing in countries with lower financial development. The analysis thus points to important interaction effects between policies and state variables, such as distance to frontier or financial development, in growth regressions. Finally, we argue that the other endogenous growth models, namely the AK and product variety models, fail to account for the evidence on the relationship between competition, education, volatility, and growth, and consequently cannot deliver relevant policy prescriptions in the three areas we consider. (JEL: O20, O30, O40)
\end{abstract}

\section{Introduction}

Suppose you are sitting on a policy panel and asked to analyze the reasons for the persistently slow growth in the EU (less than $2 \%$ a year against $3 \%$ in the US between 1995 and 2000) and come up with adequate policy recommendations. Or suppose you are asked to explain why Latin America has been leapfrogged by South-East Asia over the past thirty years, and is currently stagnating at a growth rate of $0.2 \%$ for the past five years. Your immediate reflex will probably be to dig into existing macroeconomic textbooks to see whether they have anything to offer

\footnotetext{
Acknowledgments: The 2005 Joseph Schumpeter Lecture, delivered by Philippe Aghion to the 20th Annual Congress of the European Economic Association, Amsterdam, August 25, 2005. Versions of the lecture have been presented at the Stockholm School of Economics, CID Harvard, the European Central Bank, and as the Mackintosh Lecture at Queen's University. We thank Beatriz Armendariz for helpful comments on an earlier draft, Susanne Prantl for her comments and her collaboration on empirical results reported here, and Julian Kolev and Ioana Marinescu for outstanding research assistance.

E-mail addresses: Aghion: paghion@fas.harvard.edu; Howitt: peter_howitt@brown.edu
}

Journal of the European Economic Association April-May 2006 4(2-3):269-314

(C) 2006 by the European Economic Association 
"ready-to-wear" that would help you explain the European and Latin American stagnations and find solutions to them.

However, disappointingly, there aren't many ready-to-wear items you can put in your bag from that search. The neo-classical or AK models can hardly explain why the US has been growing faster than Europe since the mid-1990s, given that the average European saving rate over the past decade has been higher than the US rate, and more importantly given that the average European capital-labor ratio has remained higher than the US ratio and has not noticeably decreased over that period. And at first sight the standard textbook innovation-based model(s) cannot account for the recent growth gap between Europe and the US, given that the property rights and innovation subsidies stressed by these models are reasonably well established in Europe, and that Europe invests almost as large a fraction of GDP on R\&D as the US ( $2 \%$ vs. $2.5 \%$ ). Moreover, these models do not seem to explain why European labor productivity growth was much higher than US growth during the 1960s and 1970s (3.5\% vs. 1.4\% on average during the 1970s), given that R\&D investments were higher in the US than Europe throughout this period.

After such a disappointing search for textbook recipes, one alternative is to turn directly to policy specialists. In particular, one may look at Dani Rodrik's (forthcoming) chapter on "Growth Strategies" or at Bill Easterly's (forthcoming) chapter on "National Policies and Economic Growth: A Reappraisal," both written for the forthcoming Handbook of Economic Growth. From Dani Rodrik's chapter one gets the important insight that "first-order economic principles (such as) protection of property rights ... (and) ... appropriate incentives ... do not map into unique policy packages" and that Asian countries have done quite well without following the policy model commonly known as "Washington consensus" (and which consists of combining full market liberalization, macroeconomic stabilization, and privatization). One also learns that the policy challenge is not only to initiate growth, but also to sustain it over the long run. However, the chapter does not provide theoretical guidelines when it comes to choosing the policy package that would be most appropriate for each particular country; the policy maker is advised to take a case-by-case approach and rely primarily on her instincts and common sense. On the other hand, Bill Easterly's chapter gives more of a chance to theory, and more specifically on the AK approach, to analyze the growth effect of policy variables such as inflation, budget balance, real overvaluation, black market premium, financial depth, and trade openness. However, when going from theory to the empirics, Easterly ends up with the disappointing conclusion that once one excludes the big outliers from cross-country regressions, one finds no significant effect of policy on growth. Thus, although very bad policies are detrimental to growth, we lose any significant effect of policy among the more moderate countries. But very bad policies in turn are likely to result from bad institutions, thus Easterly's conclusion is that all what matters at the end is 
the existence of sound basic institutions. But those already exist in Europe and yet the productivity gap between Europe and the US keeps on widening. And Latin American countries like Mexico that have conformed for more than fifteen years with the Washington Consensus blueprint keep on stagnating.

In this Schumpeter lecture, we shall argue that growth theory is in fact useful for analyzing growth policy, provided one uses an adequate growth paradigm. We posit that Schumpeterian theory in which growth results from qualityimproving innovations, provides such a paradigm and can be developed into a theory of the policy of growth. Unlike the other endogenous growth models, namely the AK model and Romer's product variety model, the Schumpeterian paradigm provides a way to "systematize" the case-by-case approach advocated by Rodrik, by pointing at key economic variables such as the country's distance to the technological frontier or its degree of financial development, that should affect the design of structural and macroeconomic policies aimed at fostering growth.

The lecture is organized as follows. Section 2 briefly reviews the three main endogenous growth paradigms: AK, the Schumpeterian framework, and the product variety model. The next sections discusses three areas in which good policy can make a difference for growth, and in particular help overcome current European stagnation. Section 3 focuses on competition and entry, and in particular explains why Europe would benefit from a competition and labor market policy that does not only emphasize competition among incumbent firms but also stresses the importance of entry, exit and mobility. Section 4 analyzes education, and argues that growth in Europe would benefit from devoting more resources to higher education. Section 5 discusses the role and design of countercyclical budgetary policies. Section 6 concludes the lecture by revisiting the role of savings in the growth process, in a way that questions the neo-classical and AK models at their very heart and also suggests new policy avenues.

\section{Three Paradigms for Analyzing Growth Policy}

To analyze policies for growth, one needs a theoretical framework in which growth is endogenous, that is, depends upon characteristics of the economic environment. That framework must account for long-term technological progress and productivity growth, without which diminishing marginal productivity would eventually choke off all growth.

The first version of endogenous growth theory was the so-called AK theory, which did not make an explicit distinction between capital accumulation and technological progress. In effect it just lumped together the physical and human capital whose accumulation is studied by neoclassical theory with the intellectual capital that is accumulated when technological progress is made. Indeed Lucas's 
(1988) influential contribution followed Uzawa (1965) in explicitly assuming that human capital and technological knowledge were one and the same. When this aggregate of different kinds of capital is accumulated there is no reason to think that diminishing returns will drag its marginal product down to zero, because part of that accumulation is the very technological progress needed to counteract diminishing returns.

According to the AK paradigm, the way to sustain high growth rates is to save a large fraction of GDP, some of which will find its way into financing a higher rate of technological progress and will thus result in faster growth. Thrift and capital accumulation are the keys, not novelty and innovation. AK theory thus formalizes the ideas behind the World Bank consensus policies after World War II, according to which the problem of economic development was underaccumulation of capital and the cure was to subsidize and give aid to large investment projects. The theory is in effect a retrospect attempt to rationalize policies which by the 1990s were already known to have failed spectacularly in the developing world (Easterly 2001, ch. 2), and in this lecture we will argue that more generally the AK approach fails to make the case for growth policy altogether.

The second wave of endogenous growth theory consists of so-called innovation-based growth models, which themselves belong to two parallel branches. One branch is the model of Romer (1990), according to which aggregate productivity is a function of the degree of product variety. Innovation causes productivity growth in the product-variety paradigm by creating new, but not necessarily improved, varieties of products. This paradigm grew out of the new theory of international trade, and emphasized the technology spillovers according to which the productivity of resources devoted to developing new product varieties was greater the greater the variety of products that have already been developed.

The other branch of innovation-based theory, first developed in our article ${ }^{1}$ and subsequently elaborated in our book, ${ }^{2}$ grew out of modern industrial organization theory, and is commonly referred to as "Schumpeterian" growth theory, because it focuses on quality improving innovations that render old products obsolete, and hence involves the force that Schumpeter called "creative destruction." In this Schumpeter lecture we shall argue that the Schumpeterian paradigm holds the best promise of delivering a systematic, integrated, and yet operational framework for analyzing and developing context-dependent growth policies, of the kind that can help putting a region like Europe back on a high growth path, whereas the $\mathrm{AK}$ and the product variety paradigms fail to fully deliver on those promises.

1. See Aghion and Howitt (1992).

2. See Aghion and Howitt (1998). 


\subsection{The AK Paradigm}

The AK paradigm is neoclassical growth theory without diminishing returns. The theory starts with an aggregate production function that is linear homogeneous in the stock of capital:

$$
Y_{t}=A K_{t},
$$

with $A$ a constant. Output is in turn divided between consumption and investment:

$$
Y_{t}=C_{t}+I_{t}
$$

and net investment is investment minus depreciation at the fixed rate $\delta$ :

$$
\dot{K}_{t}=I_{t}-\delta K_{t} .
$$

Thus the growth rate of output is the same as the growth rate of capital, which in turn depends on thrift.

In early versions of the theory, ${ }^{3}$ thrift is represented by a fixed saving ratio: $s=1-C_{t} / Y_{t}$, in which case the economy's growth rate is

$$
g=s A-\delta
$$

Alternatively, Romer's (1986) version ${ }^{4}$ represented thrift as intertemporal utility maximization à la Ramsey, in which a representative household maximizes

$$
\int_{0}^{\infty} e^{-\rho t} \frac{C_{t}^{1-\sigma}}{1-\sigma} d t
$$

subject to the production function (1), the law of motion (3), and an individual version of the resource-balance constraint (2):

$$
Y_{t}=C_{t}+(1-\tau) I_{t}+T_{t},
$$

where $\tau$ is an investment subsidy (or tax, if negative) financed by the lump-sum $\operatorname{tax} T$. The Euler equation implied by this problem determines immediately the economy's growth rate as

$$
g=\frac{\dot{C}}{C}=\frac{\frac{A}{1-\tau}-\delta-\rho}{\sigma} .
$$

An immediate implication of this model is that a higher saving rate $s$, or higher investment-subsidy rate $\tau$, encourages capital accumulation and therefore growth.

3. See Frankel (1962).

4. See also King and Rebelo (1993). 
In multi-sector versions of the AK model, the production function (1) still holds but it is recognized that $K_{t}$ can be an aggregate of different kinds of capital:

$$
K_{t}=G\left(K_{1 t}, \ldots, K_{n t}\right),
$$

with output divided between consumption and investment in the different kinds of capital according to a production-possibility frontier

$$
Y_{t}=C_{t}+J\left(\dot{K}_{1 t}+\delta_{1} K_{1 t}, \ldots, \dot{K}_{n t}+\delta_{n} K_{n t}\right),
$$

with $G$ and $J$ both being homogenous of degree one. The allocation of saving across different kinds of capital can follow different patterns, but generally there will be a growth-maximizing von Neumann ray. The rate of growth will depend not only upon thrift but also upon the how the economy distributes its saving across the different kinds of capital.

Note that AK theory constitutes a "one-size-fits-all" approach to the growth process. It applies equally to countries that are on the leading edge of the world technology frontier and to countries that are far behind. Like the neoclassical theory of Solow and Swan, it postulates a growth process that is independent of developments in the rest of the world, except insofar as international trade changes the conditions for capital accumulation. ${ }^{5}$ As we shall see in more detail, the theory is not helpful in understanding how the institutions and policies that were so successful in promoting growth immediately following World War II, when Europe was far below the frontier, turned out to produce relatively poor performance since the 1990s.

\subsection{The Schumpeterian Paradigm}

Schumpeterian theory begins with a production function specified at the industry level:

$$
Y_{i t}=A_{i t}^{1-\alpha} K_{i t}^{\alpha}, \quad 0<\alpha<1
$$

where $A_{i t}$ is a productivity parameter attached to the most recent technology used in industry $i$ at time $t$. In this equation, $K_{i t}$ represents the flow of a unique intermediate product used in this sector, each unit of which is produced onefor-one by capital. Aggregate output is just the sum of the industry-specific outputs $Y_{i t}$.

Each intermediate product is produced and sold exclusively by the most recent innovator. A successful innovator in sector $i$ improves the technology

5. See, for example, Acemoglu and Ventura (2002). 
parameter $A_{i t}$ and is thus able to displace the previous innovator as the incumbent intermediate monopolist in that sector, until displaced by the next innovator. Thus the first key implication that distinguishes the Schumpeterian paradigm from the AK and product-variety models is that faster growth generally implies a higher rate of firm turnover, because this process of creative destruction generates entry of new innovators and exit of former innovators.

Although the theory focuses on individual industries and explicitly analyzes the microeconomics of industrial competition, the assumption that all industries are ex ante identical gives it a simple aggregate structure. In particular, it is easily shown that aggregate output depends on the aggregate capital stock $K_{t}$ according to the Cobb-Douglas aggregate per-worker production function

$$
Y_{t}=A_{t}^{1-\alpha} K_{t}^{\alpha}
$$

where the labor-augmenting productivity factor $A_{t}$ is just the unweighted sum of the sector-specific $A_{i t}$ 's. As in neoclassical theory, the economy's long-run growth rate is given by the growth rate of $A_{t}$, which here depends endogenously on the economy-wide rate of innovation.

There are two main inputs to innovation; namely, the private expenditures made by the prospective innovator, and the stock of innovations that have already been made by past innovators. The latter input constitutes the publicly available stock of knowledge to which current innovators are hoping to add. The theory is quite flexible in modeling the contribution of past innovations. It encompasses the case of an innovation that leapfrogs the best technology available before the innovation, resulting in a new technology parameter $A_{i t}$ in the innovating sector $i$, which is some multiple $\gamma$ of its pre-existing value. And it also encompasses the case of an innovation that catches up to a global technology frontier $\bar{A}_{t}$ which we typically take to represent the stock of global technological knowledge available to innovators in all sectors of all countries. In the former case the country is making a leading-edge innovation that builds on and improves the leading-edge technology in its industry. In the latter case the innovation is just implementing technologies that have been developed elsewhere. ${ }^{6}$

For example, consider a country in which in any sector leading-edge innovations take place at the frequency $\mu_{n}$ and implementation innovations take place at the frequency $\mu_{m}$. Then the change in the economy's aggregate productivity parameter $A_{t}$ will be

$$
A_{t+1}-A_{t}=\mu_{n}(\gamma-1) A_{t}+\mu_{m}\left(\bar{A}_{t}-A_{t}\right),
$$

6. This flexibility of the Schumpeterian framework does not lead to a theory in which anything can happen. For example, in the next section we discuss competition and entry. As shown in Aghion et al. (2005a), the effect of competition on growth in the Schumpeterian paradigm is either monotonic or inverted-U shaped, but cannot be of any other form. Similarly, the effect of entry at the frontier on productivity growth is always more (and not less) positive in sectors initially closer to the frontier. 
and hence the growth rate will be

$$
g_{t}=\frac{A_{t+1}-A_{t}}{A_{t}}=\mu_{n}(\gamma-1)+\mu_{m}\left(a_{t}^{-1}-1\right),
$$

where

$$
a_{t}=A_{t} / \bar{A}_{t}
$$

is an inverse measure of "distance to the frontier."

Thus, by taking into account that innovations can interact with each other in different ways in different countries Schumpeterian theory provides a framework in which the growth effects of various policies are highly context-dependent. In particular, the Schumpeterian apparatus is well suited to analyze how a country's growth performance will vary with its proximity to the technological frontier $a_{t}$, to what extent the country will tend to converge to that frontier, and what kinds of policy changes are needed to sustain convergence as the country approaches the frontier.

We could take the critical innovation frequencies $\mu_{m}$ and $\mu_{n}$ that determine a country's growth path as given, just as neoclassical theory often takes the critical saving rate $s$ as given. However, Schumpeterian theory goes deeper by deriving these innovation frequencies endogenously from the profit-maximization problem facing a prospective innovator, just as the Ramsey model endogenizes $s$ by deriving it from household utility maximization. This maximization problem and its solution will typically depend upon institutional characteristics of the economy such as property rights protection and the financial system, and also upon government policy; moreover, the equilibrium intensity and mix of innovation will often depend upon institutions and policies in a way that varies with the country's distance to the technological frontier $a$.

Equation (6) incorporates Gerschenkron's "advantage of backwardness,"7 in the sense that the further the country is behind the global technology frontier (i.e., the smaller is $a_{t}$ ) the faster it will grow, given the frequency of implementation innovations. As in Gerschenkron's analysis, the advantage arises from the fact that implementation innovations allow the country to make larger quality improvements the further it has fallen behind the frontier. As we shall see, this is just one of the ways in which distance to the frontier can affect a country's growth performance.

In addition, as stressed by Acemoglu, Aghion, and Zilibotti (2002) (henceforth, AAZ), growth equations like (6) make it quite natural to capture Gerschenkron's idea of "appropriate institutions." Suppose indeed that the institutions that favors implementation innovations (that is, that lead to firms

7. See Gerschenkron (1962). 
emphasizing $\mu_{m}$ at the expense of $\mu_{n}$ ) are not the same as those that favor leadingedge innovations (that is, that encourage firms to focus on $\mu_{n}$ ). Then, far from the frontier a country will maximize growth by favoring institutions that facilitate implementation, however as it catches up with the technological frontier, to sustain a high growth rate the country will have to shift from implementation-enhancing institutions to innovation-enhancing institutions as the relative importance of $\mu_{n}$ for growth is also increasing. As formally shown in AAZ, failure to operate such a shift can prevent a country from catching up with the frontier level of per capita GDP, and Sapir et al. (2003) argued that this failure largely explains why Europe stopped catching up with US per capita GDP since of the mid-1970s.

How about growth rates? Suppose that the global frontier grows at the exogenous rate $\bar{g} .{ }^{8}$ Then equation (6) implies that in the long run a country that engages in implementation investments (with $\mu_{m}>0$ ) will ultimately converge to the same growth rate as the world technology frontier. That is, the relative gap $a_{t}$ that separates this economy from the technology frontier will converge asymptotically to the steady-state value

$$
\widehat{a}=\frac{\mu_{m}}{\bar{g}+\mu_{m}-\mu_{n}(\gamma-1)},
$$

which is an increasing function of the domestic innovation rates and a decreasing function of the global productivity growth rate. The economic force underlying this convergence in growth rates is again Gerschenkron's advantage of backwardness, according to which a country that is growing slower than the frontier rate $\bar{g}$, and which is therefore falling further behind the frontier, will therefore experience an increase in its growth rate.

Now, can we explain why, since the mid 1990s, the EU is growing at a lower rate than the US? A plausible story, which comes out naturally from the previous discussion, is that the European economy caught up technologically to the US following World War II but then its growth began to slow down before the gap with the US had been closed because its policies and institutions were not designed to optimize growth when close to the frontier. That by itself would have resulted in a growth rate that fell down to that of the US but no further. But then what happened was that the information technology (IT) revolution resulted in a revival of $\bar{g}$ in the late 1980s and early 1990s. Because Europe was as not well placed as the US to benefit from this technological revolution the result was a reversal of Europe's approach to the frontier, which accords with the Schumpeterian steady-state condition (7), and the fact that Europe is not adjusting its institutions in order to produce the growth maximizing

8. Howitt (2000) shows how the global growth rate can be endogenized as a function of innovation rates in sectors and all countries. 
innovation policy acts as a delaying force on growth convergence towards the US. ${ }^{9}$

\subsection{The Product-variety Paradigm}

The other branch of innovation-based growth theory is the product-variety model of Romer ${ }^{10}$ (1990), which starts from a Ethier-Dixit-Stiglitz production function $^{11}$ of the form

$$
Y_{t}=\sum_{0}^{N_{t}} K_{i t}^{\alpha} d i
$$

in which there are $N_{t}$ different varieties of intermediate product. By symmetry, the aggregate capital stock $K_{t}$ will be divided up evenly among the $N_{t}$ existing varieties equally, which means we can re-express this production function as

$$
Y_{t}=N_{t}^{1-\alpha} K_{t}^{\alpha}
$$

According to (8), the degree of product variety $N_{t}$ is the economy's laboraugmenting productivity parameter, and its growth rate is the economy's long-run growth rate of per-capita output. Product variety raises the economy's production potential in this theory because it allows a given capital stock to be spread over a larger number of uses, each of which exhibits diminishing returns.

The driving force of long-run growth in the product-variety paradigm is innovation, as in the Schumpeterian paradigm. In this case, however, innovations do not generate better intermediate products, just more of them. Also, as in the Schumpeterian model, the equilibrium R\&D investment and innovation rate result from a research arbitrage equation that equates the expected marginal

9. Endogenizing $\mu_{m}$ can also generate divergence in growth rates. For example, human capital constraints as in Howitt and Mayer-Foulkes (2005), or credit constraints as in Aghion, Howitt, and Mayer-Foulkes (2005), make the equilibrium value of $\mu_{m}$ increasing in $a$, which turns the growth equation (6) into a non-linear equation. That $\mu_{m}$ be increasing in $a$ follows in turn from the assumption that the cost of innovating is proportional to the frontier technology level that is put in place by the innovation, (Ha and Howitt 2005 provide empirical support for this proportionality assumption), whereas the firm's investment is constrained to be proportional to current local productivity. Then, countries very far from the frontier and/or with very low degrees of financial development or of human capital will tend to grow in the long run at a rate which is strictly lower than the frontier growth rate $\bar{g}$. However, our empirical analysis in this paper shows that this source of divergence does not apply to EU countries.

10. The semi-endogenous model of Jones (1995), in which long-run economic growth depends uniquely on the rate of population growth, might be thought of as a fourth paradigm, but it has nothing useful role to say about growth policy, since it predicts that long-run growth is independent of any policy that does not affect population growth. It does imply that innovation affects growth during the transition to the long-run but in that context it behaves just like the product-variety model that we discuss in this section.

11. See Dixit and Stiglitz (1977).

$$
\text { “zwu002060318” — 2006/6/27 — page 278 — \#10 }
$$


payoff from engaging in $R \& D$ to the marginal opportunity cost of $R \& D$. But the fact that there is just one kind of innovation, which always results in the same kind of new product, means that the product-variety model is limited in its ability to generate context-dependent growth, and is therefore of limited use for policy makers in Europe.

In particular, the theory makes it very difficult to talk about the notion of a technology frontier and of a country's distance to the frontier. Consequently, it has little to say about how the kinds of policies appropriate for promoting growth in countries near the world's technology frontier may differ from those appropriate in technological laggards, and thus to explain why Asia is growing fast with policies that depart from the Washington consensus, or why Europe has grown faster than the US during the first three decades after World War II but not thereafter. $^{12}$

In addition, nothing in this model implies an important role for exit and turnover of firms and workers; indeed, increased exit in this model can do nothing but reduce the economy's GDP, by reducing the variety variable $N_{t}$ that uniquely determines aggregate productivity according to the production function (8). As we shall argue in more details in Section 3, these latter implications of the product variety model are inconsistent with an increasing number of recent studies demonstrating that labor and product market mobility are key elements of a growth-enhancing policy near the technological frontier.

\section{Entry and Exit}

So far, competition policy in Europe has emphasized competition among incumbent firms, but paid insufficient attention to entry. Entry, as well as exit and turnover of firms, are more important in the United States than Europe. For example, $50 \%$ of new pharmaceutical products are introduced by firms that are less than 10 years old in the United States, versus only $10 \%$ in Europe. Similarly, $12 \%$ of the largest US firms by market capitalization at the end of the 1990s had been founded less than 20 years before, against only $4 \%$ in Europe, and the difference between US and Europe turnover rates is much bigger if one considers the top 500 firms.

That the higher entry costs and lower degree of turnover in Europe compared to the US are an important part of the explanation for the relatively disappointing

12. For example, Helpman (1993) uses the product-variety approach to construct a 2-country model in which innovation takes place only in the North and imitation only in the South. But although policies would then have different growth effects depending on whether implemented in the North or South, there is nothing in this analysis that links a given country's position as imitator or innovator to any productivity gap; instead it is just assumed that some countries cannot imitate and some cannot innovate. Thus there is nothing in the approach that would imply a change in appropriate institutions or policies as the country closed the gap, let alone allow for one country to leapfrog another. 
European growth performance over the past decade has been shown in empirical work by Nicoletti and Scarpetta (2003). In this section we first argue that the Schumpeterian paradigm is well-suited to analyze the effects of entry and exit on innovation and growth. We then provide evidence that is consistent with the predictions of that paradigm and questions the other two models of endogenous growth.

The section is organized as follows. Section 3.2 shows how the Schumpeterian paradigm can be used to analyze the effects of entry on innovation and growth, and contrasts the predictions delivered by this paradigm with those delivered by the other models of endogenous growth. Section 3.3 presents evidence supporting the Schumpeterian predictions. And Section 3.4 concludes.

\subsection{Product-Market Competition among Incumbents}

Like the product variety model, the Schumpeterian growth paradigm embodies the "appropriability" effect, by which stricter competition policy may reduce growth by reducing the post-innovation rents that reward a successful innovator. However, the Schumpeterian paradigm naturally generates a counteracting "escape competition" effect. That is, in duopoly industries where the two firms have similar technological capabilities, although more intense competition lowers the post-innovation rents of an innovating firm, nevertheless it may lower the rents of a non-innovating firm by even more. In such an industry, more competition thus raises the incremental profits that a firm earns by innovating; in effect, innovation is a means by which the firm can break away from the constraints of intense competition with a close technological rival. Less intense competition, on the other hand, would make it easier for the firm to earn profits without having to incur the expense of innovating. Thus more intense competition in "neck-andneck" industries can lead to higher innovation rates and hence faster productivity growth.

This escape-competition effect is likely to be dominated by the appropriability effect in unleveled industries, where one firm has a large technological lead over its rival. The leader in such an industry will not be under intense pressure to innovate regardless of the nature of competition policy. And the laggard's incentive to innovate, and therefore to catch up with the leader, may be blunted by a more vigorous anti-trust policy whose main effect would be to reduce the post-innovation profit that the firm can earn from catching up. Thus one important prediction of the Schumpeterian paradigm is that product market competition should have a more positive effect on innovation and productivity growth in industries where firms are more neck-and-neck. In Aghion, Bloom et al. (2005) this prediction is tested by examining patenting rates within a panel of UK manufacturing firms over the period 1973-1992, and the results are summarized in Figure 1A. 


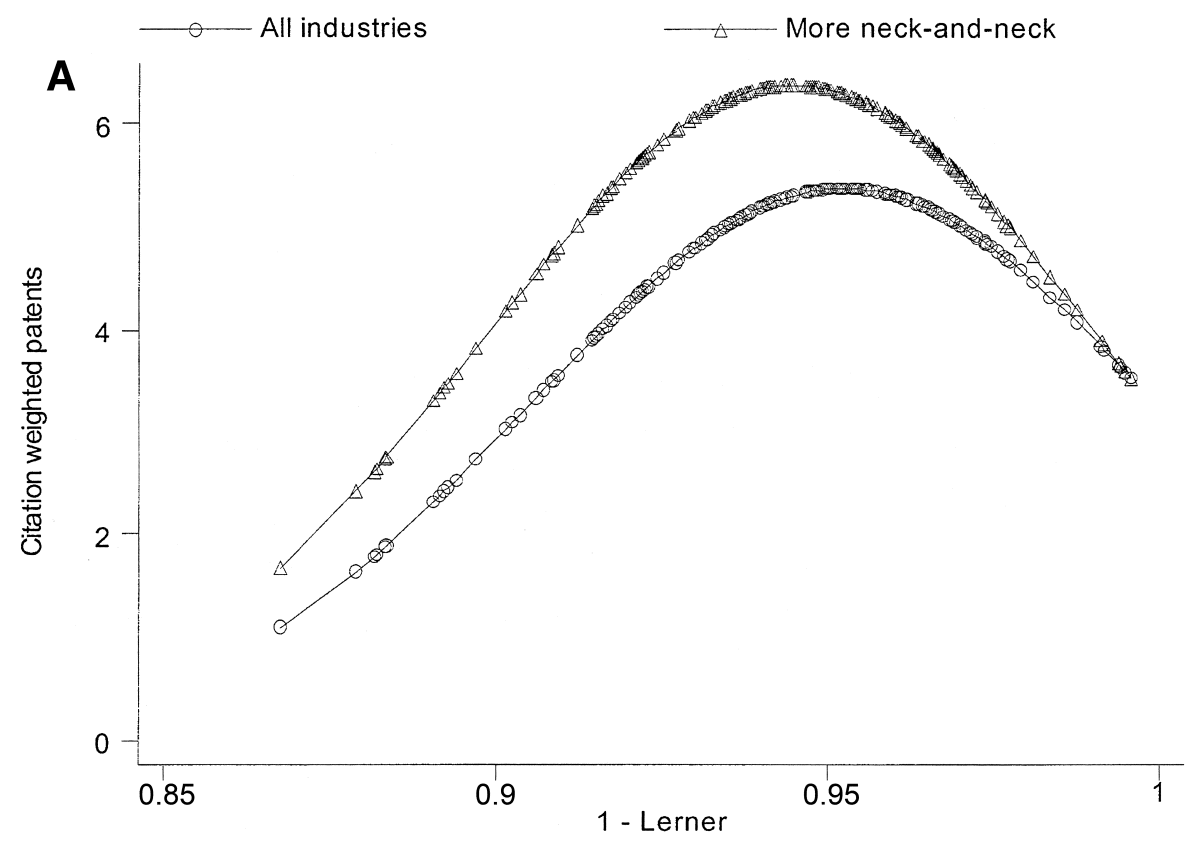

FIGURE 1A. Innovation and competition: The neck-and-neck split. The figure plots a measure of competition on the $x$-axis again citation weighted patents on the $y$-axis. Each point represents an industry-year. The circles show the exponential quadratic curve that is reported in column (2) of Table I. The triangles show the exponential quadratic curve estimated only on neck-and-neck industries that is reported in column (4) of Table III.

The figure shows that if we restrict the set of industries to those above the median degree of neck-and-neckness, the upward sloping part of the inverted-U relationship between competition and innovation is steeper than we consider the whole sample of industries. ${ }^{13}$

The non-steady-state aspects of this theory may have something to say about the recent slowdown of European growth relative to the US. That is, suppose we think of the typical European industry as involving competition between a European and a US firm. As others have observed, product-market competition tends to be less intense in the Europe than in the US. But during the immediate

13. The inverted-U feature is explained by the fact that, at high degrees of competition, the incentive to escape competition is so intense among neck-and-neck firms that industries quickly leave that state, resulting in a steady-state distribution with very few industries being neck-and-neck; thus, the overall effect of competition is the negative appropriability effect at work in unlevel industries; at low degrees of competition however the incentive to escape competition is so blunted that industries tend to remain for a long period in the neck-and-neck state, resulting in a steady-state distribution with most industries being neck-and-neck, so that the overall effect of competition is the escapecompetition effect that dominates in those industries. The explicit micro structure of Schumpeterian theory implies that these same predictions concerning a country's growth rate and innovation rate apply equally well to the growth rate and innovation rate of each industry within the country. 
post-World War II period the European firms were predominantly the technological laggards, whose innovation rates would have been diminished by very intense competition. Thus for some time the relatively non-competitive nature of Europe was favorable to innovation and productivity-growth by European firms. However, as Europe approached closer to the global technological frontier, more and more industries involved neck-and-neck competition between a European firm and its US counterpart, and it is in this situation where European innovation and growth were dampened by its non-competitive environment.

What we have here is an example of a phenomenon we explore in more detail in the following section, namely that policies which promote rapid economic growth when the economy is far from the world technology frontier may work in the opposite direction once the country has approached close to the frontier. As we shall see, this general phenomenon, which arises naturally in a Schumpeterian setting, applies to all three of the policy areas explored in this address.

Could one easily extend the product variety model in order to generate the equivalent of our escape competition effect? Our answer is no, based on the following considerations. First, the escape competition effect requires that innovations be performed by incumbent firms with positive pre-innovation rents that decrease more rapidly than post-innovation rents with competition. However, the essence of the product variety model is that growth results from the entry of new intermediate goods, and therefore by definition the innovators have preinnovation rents equal to zero. Second, escaping competition in that framework would mean differentiating oneself more from other firms. However, the DixitStiglitz specification used in that model requires all products to be equally differentiated from each other, to an extent measured (inversely) by the parameter $\alpha$, the same parameter that defines the intensity of competition between any two intermediate firms. In this framework with no quality improvement allowed, there is no means by which a firm can try to escape the effects of competition.

\subsection{Entry in the Schumpeterian Paradigm}

Even more than competition among incumbents, Schumpeterian theory implies that entry, exit, and turnover all have a positive effect on innovation and productivity growth, not only in the economy as a whole but also within incumbent firms. The idea here is that increased entry, and increased threat of entry, enhance innovation and productivity growth, not just because these are the direct result of quality-improving innovations from new entrants, but also because the threat of being driven out by a potential entrant gives incumbent firms an incentive to innovate in order to escape entry, through an effect that works much like

$$
\text { “zwu002060318" - 2006/6/27 — page } 282 \text { - \#14 }
$$


the escape-competition effect described previously. This "escape-entry" effect is especially strong for firms close to the work technology frontier. For firms further behind the frontier, the dominant effect of entry threat is a "discouragement" effect that works much like the Schumpeterian appropriability effect described above.

These effects can be understood in terms of the following simple model. ${ }^{14}$ Each sector $i$ is monopolized by an incumbent with technology parameter $A_{i t}$. Each innovation raises $A_{i t}$ by a constant factor $\gamma>1$. The incumbent monopolist in sector $i$ earns profits equal to

$$
\pi_{i t}=\delta A_{i t}
$$

In every sector the probability of a potential entrant appearing is $p$, which is also our measure of entry threat. We focus on technologically advanced entry; accordingly, each potential entrant arrives with the leading-edge technology parameter $\bar{A}_{t}$, which grows by the factor $\gamma$ with certainty each period. If the incumbent is also on the leading edge, with $A_{i t}=\bar{A}_{t}$, then we assume he can use a first-mover advantage to block entry and retain his monopoly. But if he is behind the leading edge, with $A_{i t}<\bar{A}_{t}$, then entry will occur, Bertrand competition will ensue, and the technologically dominated incumbent will be eliminated and replaced by the entrant.

The effect of entry threat on incumbent innovation will depend on the marginal benefit $v_{i t}$ which the incumbent expects to receive from an innovation. Consider first an incumbent who was on the frontier last period. If he innovates then he will remain on the frontier, and hence will be immune to entry. His profit will then be $\delta \bar{A}_{t}$. If he fails to innovate then with probability $p$ he will be eliminated by entry and earn zero profit, while with probability $1-p$ he will survive as the incumbent earning a profit of $\delta \bar{A}_{t-1}$. The expected marginal benefit of an innovation to this firm is the difference between the profit he will earn with certainty if he innovates and the expected profit he will earn if not

$$
v_{i t}=[\gamma-(1-p)] \delta \bar{A}_{t-1}
$$

Because $v_{i t}$ depends positively on the entry threat $p$, an increase in entry threat will induce this incumbent to spend more on innovating and hence to innovate with a larger probability. Intuitively, a firm close to the frontier responds to increased entry threat by innovating more in order to escape the threat.

Next consider an incumbent who was behind the frontier last period, and who will therefore remain behind the frontier even if he manages to innovate, because the frontier will also advance by the factor $\gamma$. For this firm, profits will be zero

14. The model draws on the more formal analysis of Aghion et al. (2004) and Aghion et al. (2005a).

$$
\text { “zwu002060318” — 2006/6/27 — page 283 — \#15 }
$$


if entry occurs, whether he innovates or not, because he cannot catch up with the frontier. Thus his expected marginal benefit of an innovation will be

$$
v_{i t}=(1-p)(\gamma-1) \delta A_{i, t-1} .
$$

That is, the expected benefit is a profit gain that will be realized with probability $(1-p)$, the probability that no potential entrant shows up. Because in this case $v_{i t}$ depends negatively on the entry threat $p$, therefore an increase in entry threat will induce the firm to spend less on innovating and hence to innovate with a lower probability. Intuitively, the firm that starts far behind the frontier is discouraged from innovating as much by an increased entry threat because he is unable to prevent the entrant from destroying the value of his innovation.

The theory thus generates the following predictions

1. Entry and entry threat enhance innovation and productivity growth among incumbents in sectors or countries that are initially close to the technological frontier, as the escape entry effect dominates in that case.

2. Entry and entry threat reduce innovation and productivity growth among incumbents in sectors or countries that are far below the frontier, as the discouragement effect dominates in that case.

3. Entry and entry threat enhance average productivity growth among incumbent firms when the threat has exceeded some threshold, but reduce average productivity growth among incumbents below that threshold, because as the probability $p$ measuring the threat approaches unity then almost all incumbents will be on the frontier, having either innovated last period or entered last period, and firms near the frontier respond to a further increase in $p$ by innovating more frequently.

4. Entry (and therefore, turnover) is growth-enhancing overall in the short run, ${ }^{15}$ because even in those sectors where incumbent innovation is discouraged by the threat of entry the entrants themselves will raise productivity by implementing a frontier technology.

\subsection{Evidence}

Evidence on the Growth Effects of Entry and Entry Threat. The results of this simple extension of Schumpeterian growth theory have been corroborated by a variety of empirical findings. First, Aghion, Blundell, Griffith, Howitt, and Prantt (henceforth ABGHP) (2004) investigate the effects of technologically advanced entry threat on average TFP growth of incumbent UK manufacturing establishments, using panel data with over 32,000 annual observations on

15. In the long run, the economy will grow at the same rate $\gamma-1$ as the exogenous world technology frontier.

$$
\text { “zwu002060318" - 2006/6/27 — page } 284 \text { - \#16 }
$$


about 3,800 establishments in 166 different 4-digit industries over the 1980-1993 period. They estimate the equation

$$
Y_{i j t}=\alpha+\beta E_{j t}+\eta_{i}+\tau_{t}+\varepsilon_{i j t},
$$

where $Y_{i j t}$ is TFP growth in establishment $i$, industry $j$, year $t, \eta$, and $\tau$ are fixed establishment and year effects, and $E_{j t}$ is the industry entry rate, measured by the change in the share of UK industry employment in foreign-owned plants. For the UK foreign entrants are typically US entrants, close to the technology frontier, as in the theory, whereas domestic entrants are typically smaller, less efficient, and less likely to survive.

Column 1 of Table 1 shows that OLS estimation produces a significant positive estimate of $\beta$, indicating that entry-threat, as proxied by $E_{j t}$, tends to increase the average productivity growth of incumbents. Column 2 shows that this estimate is largely unaffected by controlling for establishment-specific heterogeneity. Columns 3 and 4 are IV estimates of the equations in the first two columns respectively, where the instruments for entry exploit cross-industry and time series variation in UK product market regulation triggered by the introduction of the EU Single Market Program and US R\&D intensity in the industry. The IV estimates support the finding of a positive entry effect on average incumbent productivity growth.

This entry effect is economically as well as statistically significant. For example, according to column 3, a one-standard-deviation increase in the entry variable would raise the average incumbent's TFP growth rate by about 10 percent of the TFP growth standard deviation in the sample.

TABLE 1. Change of foreign firm share and TFP growth of domestic incumbents.

\begin{tabular}{|c|c|c|c|c|}
\hline \multicolumn{5}{|c|}{ Dependent variable: growth of total factor productivity $\mathrm{ijt}_{\mathrm{ijt}}$} \\
\hline Independent variables & OLS & OLS & IV & IV \\
\hline Change of foreign firm share ${ }_{j t}$ & $\begin{array}{l}0.0857^{* *} \\
(0.0397)\end{array}$ & $\begin{array}{l}0.0826^{*} \\
(0.0425)\end{array}$ & $\begin{array}{l}0.3814^{* * *} \\
(0.1444)\end{array}$ & $\begin{array}{l}0.3623^{* *} \\
(0.1366)\end{array}$ \\
\hline Market share $_{\text {it }-1}$ & & $\begin{array}{l}-1.0064^{* * *} \\
0.2117\end{array}$ & & $\begin{array}{l}-0.8962^{* * *} \\
0.3217\end{array}$ \\
\hline Year indicators & Yes & Yes & Yes & Yes \\
\hline $\begin{array}{l}\text { 4-digit industry indicators } \\
\text { establishment fixed effects }\end{array}$ & Yes & Yes & Yes & Yes \\
\hline Number of observations & 32,339 & 32,339 & 32,339 & 32,339 \\
\hline
\end{tabular}

Notes: OLS and IV regression results with robust standard errors in brackets are displayed. Standard errors are clustered on the 4-digit industry level. Observations are weighted by the inverse of their sampling weight times their employment. The sample consists of 32,339 observations on domestic incumbent establishments between 1981 and 1993 .

*Significant at $10 \%$. **Significant at $5 \%$. ***Significant at $1 \%$.

Source: Aghion, Blundell, Griffith, Howitt, and Prantl (2004), tables. Authors' calculations using ONS data and other data sources. All statistical results remain Crown Copyright. 
In order to support the view that this effect of entry on average incumbent productivity growth is a result of increased incumbent innovation rather than technology spillover from, or copying of, the superior technologies brought in by the entrants, ABGHP (2005) estimate non-linear patent count models equivalent to the linear productivity growth model (9). Specifically, using a panel involving over 1,000 annual observations of $176 \mathrm{UK}$ firms in 60 different 3 -digit industries over the 1987-1993 period, they use the number of patents successfully applied for by firm $i$ in the United States as dependent variable and the lagged change in the employment weighted share of new foreign-owned firms in the industry as direct measure of technologically advanced entry. A count data model with controls for year effects and unobservable firm-specific, time-invariant heterogeneity produces a highly significantly positive estimate of $\beta$. The sign and significance of the estimate is robust to the inclusion of controls for import penetration, competition, and distance to the frontier $D_{j t}$, where the latter is measured by the labor-productivity in the corresponding US industry relative to the UK industry. Instrumenting for entry using a control function approach again confirms the findings.

ABGHP (2005) provide detailed evidence that the escape entry effect is stronger for industries that are closer to the frontier. Specifically, when the interaction term $E_{j t} \cdot D_{j t}$ is added to the equation, its coefficient is highly significantly negative in all estimations. A one-standard-deviation increase in the entry variable would reduce the estimated number of patents in an industry far from the frontier (at the 90th percentile of $D_{j t}$ ) by about 3.5 percent of the patent count standard deviation in the sample and would increase the estimated number by about 12 percent in an industry near the frontier (at the 10th percentile). Figure 1 in ABGHP (2005) shows a similar picture when total factor productivity growth replaces patent count as the left-hand side variable. TFP growth in incumbent establishments that are closer to the technological frontier, reacts positively to an increase in (lagged) foreign entry whereas the opposite holds for establishments that are far from frontier. Thus it seems that the positive effect of entry threat on incumbent productivity growth in Europe is indeed much larger now than it was immediately after WWII, and that the relative neglect of entry implications of competition policy is having an increasingly detrimental effect on European productivity growth.

Evidence on the Effects of (De)regulating Entry. Evidence that the effect of regulatory policy depends on a country's circumstances is provided by Aghion, Burgess, Redding and Zilibotti (henceforth ABRZ) (2005b), who study the effects of delicensing entry in India over the period from 1980-1997, during which there were two major waves of delicensing whose timing varied across states in industries. Using an annual panel with roughly 24,000 observations on 85 industries, 
16 states, and 18 years, they show that although delicensing had no discernible effect on overall entry it did increase the dispersion of output levels across establishments in the delicensed state-industries. Thus it seems that the effects of regulatory liberalization depend upon specific industry characteristics. ABRZ focused on one specific characteristic, namely the restrictiveness of labor market regulation. They estimated an equation of the form

$$
\begin{aligned}
\ln \left(y_{i s t}\right)= & \alpha+\beta \cdot \text { delicense }_{i s t}+\gamma \cdot \text { Lreg }_{s t} \\
& +\delta \cdot \text { delicense }_{\text {sit }} \cdot \text { Lreg }_{s t}+\eta_{i s}+\tau_{t}+\varepsilon_{i j t}
\end{aligned}
$$

where $y_{i s t}$ is real output, delicense is a dummy that switches when the stateindustry is delicensed, and Lreg $_{s t}$ is a measure of the degree of pro-worker regulation. Although the coefficient $\beta$ was statistically insignificant, the interaction coefficient $\delta$ was highly significantly negative, indicating that one of the characteristics of an industry that makes it grow faster as a result of deregulation is the absence of restrictive labor-market regulation. This suggests a complementarity between different kinds of regulatory policy that needs to be taken into account when designing pro-growth policies. Relaxation of entry barriers may not succeed in promoting growth if not accompanied by other changes that are favorable to business development.

That the overall effect $\beta$ of delicensing should be negligible is consistent with the theoretical model of ABGHP (2005) we sketched previously, which says that the marginal effect of entry threat on average incumbent productivity growth will be positive only if the threat already exceeds some threshold level $\bar{p}$. Indeed, combined with the finding of ABGHP $(2004,2005)$ to the effect that the effect on overall incumbent productivity growth in the UK is positive, the result is a confirmation of this theoretical framework, became presumably entry is more open in the UK than in India, and hence the theory predicts a more significant positive effect in the UK than in India.

Generally speaking, the message of ABRZ is again that the reaction to the threat of entry posed by liberalization is different for "advanced" and "backward" state-industries in the same sector. Removing barriers to entry incentivises competitive advanced state-industries to invest in new production and management practices but may have the opposite effect on "backward" state-industries that have little chance of competing in the new environment.

Some Direct Evidence on the Growth-Enhancing Effects of Exit. Although these results are consistent with the Schumpeterian emphasis on quality-improving innovations, they are hard to reconcile with the product-variety model of Romer (1990). First, as already pointed out above, it is not clear how one would even interpret the empirical results concerning distance to the frontier in a horizontal 
innovation model (because in that framework there are no productivity differences between industries). Second, it is hard to see how the threat of entry or competition could promote innovation among incumbents. This section describes a variety of additional empirical findings indicating that quality improvement and creative destruction are indeed a necessary part of the mechanism by which entry promotes growth.

First, in ongoing work with Pol Antras and Susanne Prantl, we use UK establishment-level panel data and information on industry-level input-output linkages to estimate the effect on TFP growth arising from growth in high-quality input in upstream industries, and also from exit of obsolete input-production firms in upstream industries. Specifically, we take a panel of more than 23,000 annual observations on about 5,000 establishments in 180 4-digit industries between 1987 and 1993, together with the 1984 UK input-output table, to estimate an equation of the form

$$
g_{i j t}=\alpha+\beta \cdot q_{j t-1}+\gamma \cdot x_{j t-1}+\delta \cdot Z_{i j t-1}+\eta_{i}+\tau_{t}+\varepsilon_{i j t},
$$

where $g_{i j t}$ is the TFP growth rate of establishment $i$ in industry $j$. The first regressor is our measure of upstream quality improvement, calculated as

$$
q_{j t-1}=\sum_{k \neq j} a_{k j} \cdot \Delta f_{k t-1}
$$

where $a_{k j}$ is the ratio of sector $j$ 's total inputs supplied by UK sector $k$ plus imported sector $k$-goods based on the input-output table, and $f_{k t-1}$ is the foreignfirm market share of sector $k$ in $t-1$. The second regressor is our measure of exit of obsolete upstream production, calculated as

$$
x_{j t-1}=\sum_{k \neq j} a_{k j} \cdot\left(\sum_{i=1}^{N_{k t-2}} L_{i t-2} \cdot P_{i t-1}\right) / \sum_{i=1}^{N_{k t-2}} L_{i t-2},
$$

where $P_{i t-1}$ equals one if plant $i$ exits between year $t-2$ and year $t-1$ in industry $k$, and $L_{i t-2}$ is employment in that plant in year $t-2$. Establishment and time fixed effects are included, along with other controls in $Z_{i j t-1}$, including a measure of the establishment's lagged market share.

The result of this estimation is a significant positive effect of both upstream quality improvement and obsolete input production. These results are robust to taking potential endogeneity into account by applying an instrumental variable approach and to controlling for $g$ and $x$ on the downstream industry level itself.

$$
\text { “zwu002060318" - 2006/6/27 — page } 288 \text { - \#20 }
$$


The effects are particularly strong for establishments that use more intermediate inputs; that is, establishments with a share of intermediate product use above the sample median. Altogether, the results we find are consistent with the view that quality-improving innovation is an important source of growth. The results are however not consistent with the horizontal innovation model, in which there should be nothing special about the entry of foreign firms, and according to which the exit of upstream firms should if anything reduce growth by reducing the variety of inputs being used in the industry.

Comin and Mulani (2005) have produced additional evidence to the effect that exit as well as entry is important to the growth process. Using a sample of US firms they show that, according to two measures of turnover in industry leadership that they construct, turnover is positively related to earlier R\&D. Again, this is evidence of a creative-destruction element to the innovation process that one would not expect to find if the primary channel through which innovation affected economic growth was by increasing product variety. Indeed the product-variety theory has little to say at all about how productivity varies across firms in an industry, let alone how the productivity ranking would change over time.

In addition to these results, Fogel, Morck, and Yeung (2005) have produced evidence to the effect that country-level GDP growth is linked to the turnover of dominant firms. Using data on large corporate firms in 44 different countries over the 1975-1996 period, they find that economies whose top 1975 corporations declined more grow faster than other countries with the same initial per-capita GDP, level of education, and capital stock. Again, this evidence of an association between growth and creative destruction has no counterpart in the horizontalinnovation theory.

\subsection{Taking Stock}

What have we learned from our discussion in this section? First, we have seen that empirical evidence strongly supports the main prediction of the Schumpeterian model, namely that (i) entry and delicensing have a more positive effect on growth in sectors or countries that are closer to the technological frontier, but have a less positive effect on sectors or countries that lie far below the frontier; and (ii) exit can have a positive effect on productivity growth in downstream industries because it replaces less efficient input producers by more efficient ones. However, the same findings seriously question what the other models of endogenous growth have to say on how growth is affected by competition and entry policy. AK theory is simply silent on this topic, as up to now it has been developed exclusively using the theory of perfect competition. And the product variety model delivers counterfactual predictions, namely, (a) that increased product market competition, which in that 
model corresponds to a higher degree of substitutability between intermediate inputs, has an unambiguously negative effect on productivity growth as it reduces the monopoly rents accruing to a successful innovator and therefore her incentive to invest in $R \& D$; this prediction is at odds with a variety of evidence, especially the results of Nickell (1996) and Blundell, Griffith, and Van Reenen (1995) to the effect that UK manufacturing firms tended to have faster TFP growth rates, and higher innovation rates, in industries facing more intense product-market competition; (b) that entry is growth-enhancing no matter the country's or sector's level of technological development, unlike what we have shown above based on UK or Indian cross-industry data; (c) that exit reduces growth by reducing product variety; however we saw that current work by Fogel, Morck, and Yeung (2005), by Comin and Mulani (2005), and by our joint work with Pol Antras and Susanne Prantl, all point to positive effects of exit and/or turnover on growth.

Second, the analysis and empirical findings reported here have important policy implications. In particular, they go directly against the belief that national or European "champions" are best placed to innovate at the frontier, or that these should be put in charge of selecting new research projects for public funding, as recently proposed by Jean-Louis Beffa of Saint-Gobain in a report to President Chirac. Instead, as we recommended in Sapir et al. (2003), any product market regulation, including the Single Market legislation, should be reexamined for its effects on new entry. In the past competition policy in Europe has been used to a large extent as a mechanism to increase openness and integration (in particular through the design and enforcement of the dominance criterion), not so much competition per se, and if it has affected competition it is mainly by policing anti-competitive behavior among incumbent firms, while paying little attention to entry. The Schumpeterian model in this section, and the evidence supporting it, suggest that although disregarding entry was no big deal during the 30 years immediately after World War II when Europe was still far behind the US and catching up with it, nevertheless now that Europe has come close to the world technology frontier this relative neglect of entry considerations is having an increasingly depressing effect on European growth.

\section{Education}

Is the European education system growth-maximizing? A first look at the US versus the EU in 1999-2000 shows that $37.3 \%$ of the U.S. population aged 25-64 have completed a higher education degree, against only $23.8 \%$ of the EU population. This educational attainment comparison is mirrored by that on tertiary education expenditure, with the US devoting 3\% of its GDP to tertiary education versus only $1.4 \%$ in the EU. Is this European deficit in tertiary education investment a big deal for growth? 


\subsection{Mankiw-Romer-Weil and Lucas}

Once again, our first reflex is to get back to the literature on education and growth. First, to models based on capital accumulation. There, the neo-classical reference is Mankiw, Romer, and Weil (1992) (henceforth MRW), and the AK reference is the celebrated article by Lucas (1988). Both papers emphasize human capital accumulation as a source of growth. In MRW, which is an augmented version of the Solow model with human capital as an additional accumulating factor of production, human capital accumulation slows down the convergence to the steady-state by counteracting the effects of decreasing returns to physical capital accumulation. In Lucas, instead, the assumption that human capital accumulates at a speed proportional to the existing stock of human capital leads a positive longrun growth rate. Whether on the transition path to the steady-state (in MRW) or in steady-state (in Lucas), the rate of growth depends upon the rate of accumulation of human capital, not upon the stock of human capital. Moreover, these capital accumulation-based models do not distinguish between primary/secondary and tertiary education: The two are perfect substitutes in these models. Thus, if we believe these models, it is not a problem if the US spends more than Europe in higher education, as long as total spending and attainment in education as a whole have not increased faster in the US than in Europe. And indeed they have not done so over the past decade.

Does this mean that education policy is not an issue, or rather that we should not fully believe in these models? What tilts us more towards the latter is first the work by Benhabib and Spiegel (1994) who argued, based on cross-country regressions over the 1965-1985 period, that human capital accumulation (where human capital is measured by school enrollment) was not significantly correlated with growth, whereas human capital stocks were. Another source of scepticism is the finding by Ha and Howitt (2005) that the trend growth rate of the number of R\&D workers in the US has gone down over past 50 years, whereas the trend rate of productivity growth has not.

\subsection{Nelson-Phelps and the Schumpeterian Approach}

More than just questioning the capital accumulation approach to education and growth, Benhabib and Spiegel (1994) provided support to the Schumpeterian approach by resurrecting the simple model by Nelson and Phelps (1966). Nelson and Phelps did not have a model of endogenous growth with endogenous R\&D and innovation, but they were already thinking of growth as being generated by productivity-improving adaptations, whose arrival rate would depend upon the stock of human capital. More formally, Nelson and Phelps would picture a world economy in which, in any given country, productivity grows according to an 
equation of the form

$$
\dot{A}=f(h)(\bar{A}-A),
$$

where again $\bar{A}$ denotes the frontier technology (itself growing over time at some exogenous rate), and $h$ is the current stock of human capital in the country. A higher stock of human capital would thus foster growth by making it easier for a country to catch up with the frontier technology. Benhabib and Spiegel tested a slightly augmented version of the Nelson-Phelps model in which human capital does not only facilitate the adaptation to more advanced technologies, by also makes it easier to innovate at the frontier, according to a dynamic equation of the form

$$
\dot{A}=f(h)(\bar{A}-A)+g(h) \gamma A,
$$

where the second term capture the innovation component of growth.

Using cross country-regressions of the increase in the log of per capita GDP over the period 1965-1985 as a linear function of the sum of logs of human capital stocks over all the years between 1965 and 1985, Benhabib and Spiegel found a significantly positive correlation between the two, which in turn was evidence that the rate of productivity growth is also positively correlated with the stock of human capital. Moreover, Benhabib and Spiegel found a larger correlation for countries further below the world technology frontier, which would hint at the catch-up component of growth being the dominant one. Thus, more than the rate of human capital accumulation, it is its stock that matters for growth. Does this help us understand the comparison between Europe and the US?

Unfortunately, more recent work by Krueger and Lindahl (2001) would temper our optimism. Using panel data over 110 countries between 1960 and 1990, choosing the number of years in education instead of the logarithm of that number to measure human capital, ${ }^{16}$ and correcting for measurement errors, Krueger and Lindahl would still find a positive correlation between growth and human capital stocks (although they also found a positive correlation between growth and the

16. This change was in turn motivated by the so-called Mincerian approach to human capital, whereby the value of one more year in schooling is measured by the wage increase that is foregone by the individual who chooses to study during that year instead of working. This amounts to measuring the value of a human capital stock by the log of the current wage rate earned by an individual. And that log was shown by Mincer to be positively correlated to the number of years spend at school by the individual, after estimating an equation of the form

$$
\ln w=a_{0}+a_{1} n
$$

The Mincerian approach can itself be criticized, however, for: (i) assuming perfectly competitive labor markets; (ii) ignoring the role of schools as selection devices; and (iii) ignoring interpersonal and intertemporal knowledge externalities.

$$
\text { “zwu002060318” — 2006/6/27 — page } 292 \text { — \#24 }
$$


rate of accumulation of human capital), however the significance of the correlation between growth and human capital stocks would disappear when restricting the regression to OECD countries.

\subsection{Schumpeter meets Gerschenkron}

Should we conclude from Krueger and Lindahl (2001) that education only matters for catching-up but not for innovating at the frontier and that, consequently, education is not an area which Europe needs to reform in order to resume growing at a rate at least equal to that of the US? The new hint at that point came from AAZ's (2002) idea on appropriate institutions and economic growth, which we already spelled out in Section $2^{17}$ As in Benhabib and Spiegel (1991), productivity growth in AAZ can be generated either by implementing (or imitating) the frontier technology or by innovating on past technologies, and obviously the relative importance of innovation increases as a country or region moves closer to the technology frontier. However, and this is where we use AAZ and thereby depart from Benhabib and Spiegel, different types of education spending lie behind imitation and innovation activities. In particular, higher education investment should have a bigger effect on a country's ability to make leadingedge innovations, whereas primary and secondary education are more likely to make a difference in terms of the country's ability to implement existing (frontier) technologies.

Distance to Frontier and the Composition of Education Spending. Now, what are the potential implications of this approach for education policy, and is there something to learn from the comparison between Europe and the US given the disappointing news of Krueger and Lindahl from cross-OECD country regressions? The remaining part of the section is based on work by Vandenbussche, Aghion, and Meghir (2004) (henceforth VAM), and current work by Aghion, Boustan, Hoxby, and Vandenbussche (2005) (henceforth ABHV). The starting point of these two papers is that, in contrast to the Nelson-Phelps or Benhabib-Spiegel models, human capital does not affect innovation and imitation uniformly: More specifically, primary/secondary education tends to produce imitators, whereas tertiary (especially graduate) education is more likely to produce innovators. This realistic assumption, in turn, leads to the prediction that, as a country moves closer to technological frontier, tertiary education should become increasingly important for growth compared to primary/secondary education (all measured in stocks).

17. That hint in turn provided the backbone for the Sapir Report and its application to education lead to a report on "Education and Growth" for the French Conseil d'Analyse Economique. 
First, note that this simple combination of AAZ with the Nelson-Phelps model of education and growth, provides a solution to the Krueger-Lindahl puzzle. Namely, that total human capital stock

$$
U+S
$$

is not a sufficient statistics to predict growth in OECD countries. For example, take two countries $A$ and $B$ at same distance of world frontier, with same total human capital, but

$$
S_{A}>S_{B}
$$

Country $A$ will grow faster if the two countries are sufficiently close to frontier whereas country $B$ will grow faster if both countries are far from frontier, and yet the two countries have the same total amount of human capital.

Now, going in slightly greater details into formalization, VAM and ABHV focus on the following class of productivity growth functions:

$$
A_{i t}-A_{i t-1}=u_{m, i, t}^{\sigma} s_{m, i, t}^{1-\sigma} \bar{A}_{t-1}+\gamma u_{n, i, t}^{\phi} s_{n, i, t}^{1-\phi} A_{t-1}=g(u, s),
$$

where $\bar{A}_{t-1}$ is the frontier productivity last period, $A_{t-1}$ is the average productivity in the country last period, $u_{m}$ (resp. $u_{n}$ ) is the number of workers with primary/secondary education (unskilled workers) used in imitation (resp. innovation), $s_{m}$ (resp. $s_{n}$ ) is the number of workers with higher education (skilled workers) in imitation, and

$$
u=\left(u_{m}, u_{n}\right) ; s=\left(s_{m}, s_{n}\right),
$$

and

$$
\sigma>\phi
$$

so that the elasticity of productivity growth with respect to skilled (resp. unskilled) workers is larger in innovation (resp. in imitation).

Letting $a_{t}=A_{t} / \bar{A}_{t}$ denote the country's proximity to the technological frontier at date $t$, and letting the frontier grow at constant rate $\bar{g}$, the intermediate producer will choose $u$ and $s$ to maximize profits. Dividing through by $\bar{A}_{t-1}$ and dropping time subscripts, the producer's problem simply becomes

$$
\max _{u_{m}, u_{n} s_{m}, s_{n}}\left\{\delta\left[u_{m}^{\sigma} s_{m}^{1-\sigma}+\gamma u_{n}^{\phi} s_{n}^{1-\phi} a\right]-w_{u}\left(u_{m}+u_{n}\right)-w_{s}\left(s_{m}+s_{n}\right)\right\}
$$

$$
\text { “zwu002060318" — 2006/6/27 — page } 294 \text { — \#26 }
$$


where we eliminate the firm's subscript $i$ because all intermediate firms face the same maximization problem. Moreover, in equilibrium we necessarily have

$$
u_{m}+u_{n}=U ; s_{m}+s_{n}=S,
$$

where $U$ and $S$ are the total supplies of workers with primary/secondary education and tertiary education respectively.

What we have here is formally equivalent to a small open economy model with two factors and two products, where the two products are imitation and innovation, whose prices, $\delta$ and $\delta \gamma a$, are exogenously given. As in standard trade theory, these given output prices uniquely determine the equilibrium factor prices $w_{u}$ and $w_{s}$. The "revenue" in firms' objective function is proportional to the growth rate (plus unity). Solving for the equilibrium allocations of skilled and unskilled labor between imitation and innovation as a function of $U, S$ and the proximity $a$ to the technological frontier, one can look at how the equilibrium growth rate

$$
g^{*}(U, S, a)=g\left(u^{*}(U, S, a), s^{*}(U, S, a)\right)
$$

varies with either of those three variables.

In particular, looking at the cross derivative of $g^{*}$ with respect to $S$ and $a$, we find

$$
\frac{\partial^{2} g^{*}}{\partial a \partial S}>0
$$

in other words, a marginal increase in the fraction of workers with higher education enhances productivity growth all the more the closer the country is to the world technology frontier.

The intuition for this result relies on the Rybczynski theorem in international trade, which in turn implies that a marginal increase in the supply $S$ of highly educated workers leads to an even greater number of skilled workers being employed in innovation. Because the change does not affect equilibrium factor prices, therefore it leaves the factor proportions unchanged in each activity, meaning that innovation also attracts an increased number of unskilled workers. More precisely, because $\sigma>\phi$, so that innovation is the skill-intensive activity, innovation will increase but imitation will decrease. The effect on firms' "revenue," and hence the effect on the economy's growth rate, is positive. For countries closer to the frontier, where "price" of innovation $\delta \gamma a$ is larger, the effect is larger than for countries further from the frontier.

$$
\text { “zwu002060318” — 2006/6/27 — page } 295 \text { — \#27 }
$$


Cross-Country Evidence. VAM confront this prediction with cross-country panel evidence on higher education, distance to frontier, and productivity growth. ABHV tests the theory on cross-US state data. Each approach has its pros and cons. Cross-US-state analysis uses a much richer data set and also very good instruments for higher and lower education spending. However, a serious analysis of the growth impact of education spending across US states must take into account an additional element not considered in previous models, namely the effects on the migration of skilled labor across states at different levels of technological development. On the other hand, cross-country analysis can safely ignore the migration, however the data are sparse and the instruments for educational spending are weak (they mainly consists of lagged spending). In the remaining part of the section we shall consider the two pieces of empirical analysis in turn.

VAM consider a panel data set of 22 OECD countries over the period 19602000, which they subdivide into five-year subperiods. Output and investment data are drawn from Penn World Tables 6.1 and human capital data from Barro and Lee (2000). The Barro and Lee data indicate the fraction of a country's population that has reached a certain level of schooling at intervals of five years, so they use the fraction that has received some higher education together with their measure of total factor productivity (TFP) (constructed assuming a constant labor share of 0.65 across country) to perform the regression

$$
g_{j, t}=\alpha_{0}+\alpha_{1} \operatorname{dist}_{j, t-1}+\alpha_{2} \Lambda_{j, t}+\alpha_{3}\left(\text { dist }_{j, t-1} * \Lambda_{j, t}\right)+v_{j}+u_{j, t},
$$

where $g_{j, t}$ is country $j$ 's growth rate over a five-year period, dist ${ }_{j, t-1}$ is country $j$ 's closeness to the technological frontier at $t-1$ (i.e., 5 years before), $\Lambda_{j, t}$ is the fraction of the working age population with some higher education, and $v_{j}$ is a country's fixed effect. The closeness and human capital variables are instrumented with their values at $t-2$ and the equation is estimated in differences to eliminate the fixed effect. Before controlling for country fixed effects, VAM obtain a statistically significant coefficient of -1.87 for the human capital variable, and a statistically significant coefficient of 2.37 for the interaction variable, indicating that indeed higher education matters more as a country gets closer to the frontier. Controlling for country fixed effects removes the significance of the coefficients, however this significance is restored once country are regrouped into subregions and country fixed effects are replaced by group fixed effects. This, in turn, suggests that cross-country data on only 22 countries are too sparse for significant regression results to survive when we control for country fixed effects.

To see how this result translates in terms of the effect of an additional year of schooling of higher education, they perform the following regression in logs:

$$
g_{j, t}=\alpha_{0}^{\prime}+\alpha_{1}^{\prime} \operatorname{dist}_{j, t-1}^{\prime}+\alpha_{2}^{\prime} N_{j, t}+\alpha_{3}^{\prime}\left(\text { dist }_{j, t-1} * N_{j, t}\right)+v_{j}^{\prime}+u_{j, t}^{\prime},
$$


where this time dist $_{j, t-1}^{\prime}$ is the log of the closeness to the technological frontier and $N_{j, t}$ is the average number of years of higher education of the population. The econometric technique employed is the same as before. Before controlling for country fixed effects, VAM find the coefficient of the number of years to be 0.105 and of little significance, but the coefficient of the interaction variable to be equal to 0.368 and significant. This result again demonstrates that it is more important to expand years of higher education close to the technological frontier.

Cross-US-States Evidence. ABHV test the same theory on cross-US-state data instead of cross-country data. As we mentioned, one potential problem when moving from cross-country to cross-region data, is that educational policy should affect migration flows across regions more than it affects migration flows across countries. Thus a suitable model of education and growth across regions within a same country ought to include an additional equation describing how migration flows varies for example with the wage differential between a particular state and the state currently at the technological frontier. Introducing the possibility of migration reinforces the positive interaction between closeness to the frontier and higher education. Namely, in addition to the Rybczynski effect described previously, investing in higher education in a state that is far from the technological frontier would contribute all the less to growth in that state that the newly skilled workers would migrate to a more frontier state where productivity and therefore wages are higher.

Any regression with growth on the left-hand-side and education on the righthand-side raises an obvious endogeneity problem, best emphasized by Bils and Klenow (2000). Here, as in the above cross-country panel regressions, the endogeneity problem can be stated as follows: If states or countries choose their composition of education spending according to the model, then we should see the composition of educational investments being highly correlated with technology and productivity, and therefore the regressions would say nothing about causality.

However, the great advantage of moving from cross-country to cross-state analysis is that we have access to a natural source of exogenous mistakes in education investment, namely political economy considerations which may lead the congress or other federal instances to misallocate the funding to higher education across states. For example, because it has a representative on a congressional commission for higher education, a far-from-the-frontier state may end up mistakenly receiving excessive funding for research-related education. Conversely, because of local political economy considerations, a close-to-the-frontier state may end up mistakenly focusing its investment in primary education, neglecting higher education.

In other words, political economy considerations and the politicians's ability and incentive to deliver "porks" to their constituencies, provide a natural source 
of instruments that predict states' tendencies to make exogenous mistakes when investing in education.

The actual instruments used in ABHV are the following:

1. For research-university education: Whether a state has a congressman on the appropriations committee which allocate funds for research universities but not other types of schools.

2. For "low-brow" post-secondary education (community colleges, training schools): Whether the chairman of the state's education committee represents voters whose children attend one- or two-year postsecondary institutions.

3. For primary and secondary education: Whether the overall political balance on the state's supreme court interacts with the state school finance system.

Then, using annual panel data over the period 1970-2000, ABHV perform a two-stage procedure whereby: (i) In first-stage regressions, the various kinds of educational spending are regressed over their respective instruments; and (ii) the growth rate in each state and year, is regressed over the instruments for the various kinds of educational spending, the state's proximity to the frontier, and the interaction between the two, controlling for state and year fixed effects.

We refer our readers to ABHV (2005) for the detailed regression results, which yield the following conclusions. First, in contrast to our previous crosscountry analysis, here the correlations remain significant even after controlling for state fixed effects without having to regroup the country dummies. Second, the above instruments are very strong, with an $F$-statistic of more than 10 for the joint significance of the two dummies for senator and house representative on the corresponding appropriation committees as determinants of research education spending. For example, every additional representative on the House Appropriation committee increases the expenditure on research-type education by $\$ 597$ per cohort member, which is considerable. Now, turning to the second-stage regressions, ABHV find that an additional $\$ 1,000$ per person in research education spending raises the state's per-employee growth rate by $0.27 \%$ if the state is at the frontier (with $a$ close to 1 ), whereas it raises it by only $0.09 \%$ if the state is far from the frontier (with $a$ close to 0.3). More generally, the closer a state gets to the technological frontier, the more growth-enhancing it becomes to invest in higher education and the less growth-enhancing it becomes to emphasize lower education.

\subsection{Taking Stock}

What have we learned from our discussion in this section? First, that capital accumulation-based models have little to say about education policy, particularly with regard to the increasing growth gap between Europe and the US. Second, 
that Schumpeterian models that emphasize the interplay between human capital stocks and the innovation process have more potential for delivering policy recommendations, yet when looking at educational spending as a whole there is not much that be said from looking at cross-OECD comparisons. However, once we distinguish between imitation and frontier innovation and map these two sources of productivity growth to different segments of the education system, then we can come up with relevant policy recommendations for regions like Europe that have moved closer to the frontier and yet are maintaining very low levels of higher education spending compared to the US. The above regressions suggest indeed that putting the emphasis on primary/secondary education was fine as long as Europe was technologically far from the US and therefore relying more on imitation as a main source of growth, but that now that the growth potential of imitation is wearing out, it becomes more urgent to invest more in higher education in order to foster innovation. In fact, the cross-country (cross-OECD) analysis in VAM shows the additional result that if we include a dummy for 1985 (equal to zero before 1985 and to one after) in the regressions, and interact that dummy with all the right-hand-side terms in the regression, one finds that after 1985 , the interaction between higher education investment and the proximity to the technological frontier, becomes insignificant: This, in turn indicates that on top of the above consideration, something happened during the 1980s (globalization and/or the IT revolution?) that would make it more growth-enhancing for all OECD countries to shift their emphasis higher education.

\section{Macropolicy}

There is a common prejudice in macroeconomics, which is widely shared among policymakers, which they learned in their undergraduate education years and which we still see being developed in most textbooks of intermediate macroeconomics: Namely, that there is a perfect dichotomy between on the one hand macroeconomic policy (budget deficit, taxation, money supply) taken to affect primarily the short-run and whose primary aim is to stabilize the economy; and on the other hand, long-run economic growth, which is either taken to be exogenous or to depend only upon structural characteristics of the economy (property right enforcement, market structure, market mobility, and so forth). The only link between macropolicy and long-run growth that most policy makers believe in is that growth requires macroeconomic stability, everything else remaining equal.

\subsection{The Failure of the AK Attempt}

The first attempt at overcoming this dichotomy between short-run and longrun came with the AK wave of endogenous growth models. Thus Easterly

$$
\text { “zwu002060318” — 2006/6/27 — page } 299 \text { — \#31 }
$$


(forthcomming) shows that the effect of taxation on growth can be much reduced when output is produced using two types of capital, one that is produced by the formal sector and can therefore be taxed, whereas the other type is produced by the informal sector and thus immune from taxation. Obviously, an increased tax rate on formal sector capital will induce individual producers to resort more to the informal sector capital, hence a smaller effect on growth if the two types of capital goods are (sufficiently) close substitutes. More fundamentally, Easterly points out that poor institutions will lead to a low value of $A$, which by itself will reduce the growth impact of any macroeconomic policy.

Going from theory to empirics, Easterly (forthcomming) considers six variables, some of which are more structural (like financial depth) and others which are more policy (inflation, budget balance, real overvaluation, trade openness, and black-market premium). He then regresses growth over these variables, using a cross-country panel of five-year averages over the 1960-2000 period. His Table 4 shows significant effects of these variables on growth, with the expected signs (for example, higher inflation, which implies a higher inflation tax, is detrimental to growth, budget balance is growth-enhancing as it predicts a lower tax rate in the future etc.). Unfortunately, as shown in his Table 6, all these effects become insignificant if we remove countries for which policies are extreme (e.g., countries with inflation rates greater than $30 \%$ or with budget deficits higher than $12 \%$ of GDP). Thus, if extreme policies are bad for growth, macropolicy and policy in general should have no impact on growth if we restrict the analysis to reasonable countries. In particular, given that both EU countries and the US fall into the latter category, the analysis in Easterly (forthcomming) would imply that macropolicies have nothing to do with explaining the increasing growth gap between the EU and the US.

One could argue that Easterly restricts his analysis to average policies over time and ignores the existence of shocks and business cycles. He therefore abstracts from the potential effects that macropolicies could have on growth, for example through stabilizing the economy and helping individual producers smooth out the effects of cycles and shocks. However, AK models of volatility and growth have been developed by King and Rebelo (1993), Stadler (1990) and more recently by Jones, Manuelli, and Stacchetti (2001). The idea in these models is that macroeconomic volatility may affect longrun growth through its effects on aggregate savings and investment (recall that in the AK framework, growth is entirely driven by capital accumulation). Thus higher volatility will tend to increase the supply of savings as individuals will wish to save more for precautionary motives; but higher volatility will tend to reduce the demand for investment as it will reduce the risk-adjusted rate of return on investment. Jones, Manuelli, and Stacchetti show that which of these latter two effects dominates depends upon the representative household's elasticity of intertemporal substitution. This is all very nice and elegant, 
but if we now take a look at cross country or panel regressions of growth on volatility or commodity price shocks, as in Table 2, drawn from Aghion, Angeletos, Banerjee and Manova (2005) (henceforth AABM), we see that controlling for total investment over GDP reduces the (negative) correlation between volatility and growth (or the positive correlation between good shocks and growth) by only $20 \%$ and without reducing the significance of these correlation terms.

This, in turn implies that total investment cannot be the main channel whereby a stabilizing macroeconomic policy may affect growth through affecting the impact of volatility. Thus, once again, we need to move out of AK and consider alternative models of endogenous growth. ${ }^{18}$

\subsection{A Schumpeterian Approach to Volatility and Growth}

A more Schumpeterian view of business cycles and growth is that recessions provide a cleansing mechanism for correcting organizational inefficiencies and for encouraging firms to reorganize, innovate, or reallocate to new markets. The cleansing effect of recessions is also to eliminate those firms that are unable to reorganize or innovate. Schumpeter himself would summarize that view as follows: "[Recessions] are but temporary. They are means to reconstruct each time the economic system on a more efficient plan" (Schumpeter 1934). Now, if firms could always borrow enough funds to either reorganize their activities or move to new activities and markets, and the same was true for workers trying to relocate from one job to another, the best would be to recommend that governments do not intervene over the business cycle, and instead let markets operate.

However, as emphasized by Aghion, Angeletos, Banerjee, and Manova (2005) (AABM), things become quite different when credit market imperfections prevent firms from innovating and reorganizing in recessions. In particular, suppose that firms can choose between short-run capital investment and longterm R\&D investment (this choice amounts to a research arbitrage condition).

18. Krebs (2003) has a 2-sector AK model that produces a negative effect of volatility on growth even with a unitary elasticity of intertemporal substitution. In his model, the main impact of volatility on the representative household is to increase the variance of uninsurable human-capital shocks (for example, spells of unemployment), which leads the household to invest too little in human versus physical capital, taking the economy away from the growth-maximizing von Neumann ray. This is also an effect which depends upon financial development, to the extent that increased financial development brings about more complete risk-sharing arrangements and therefore reduces the extent of underinvestment in human capital. To rule out Krebs's interpretation of the correlation between volatility and growth we would have to control for investment rates in both human and physical capital, allowing for the composition of investments to matter. 


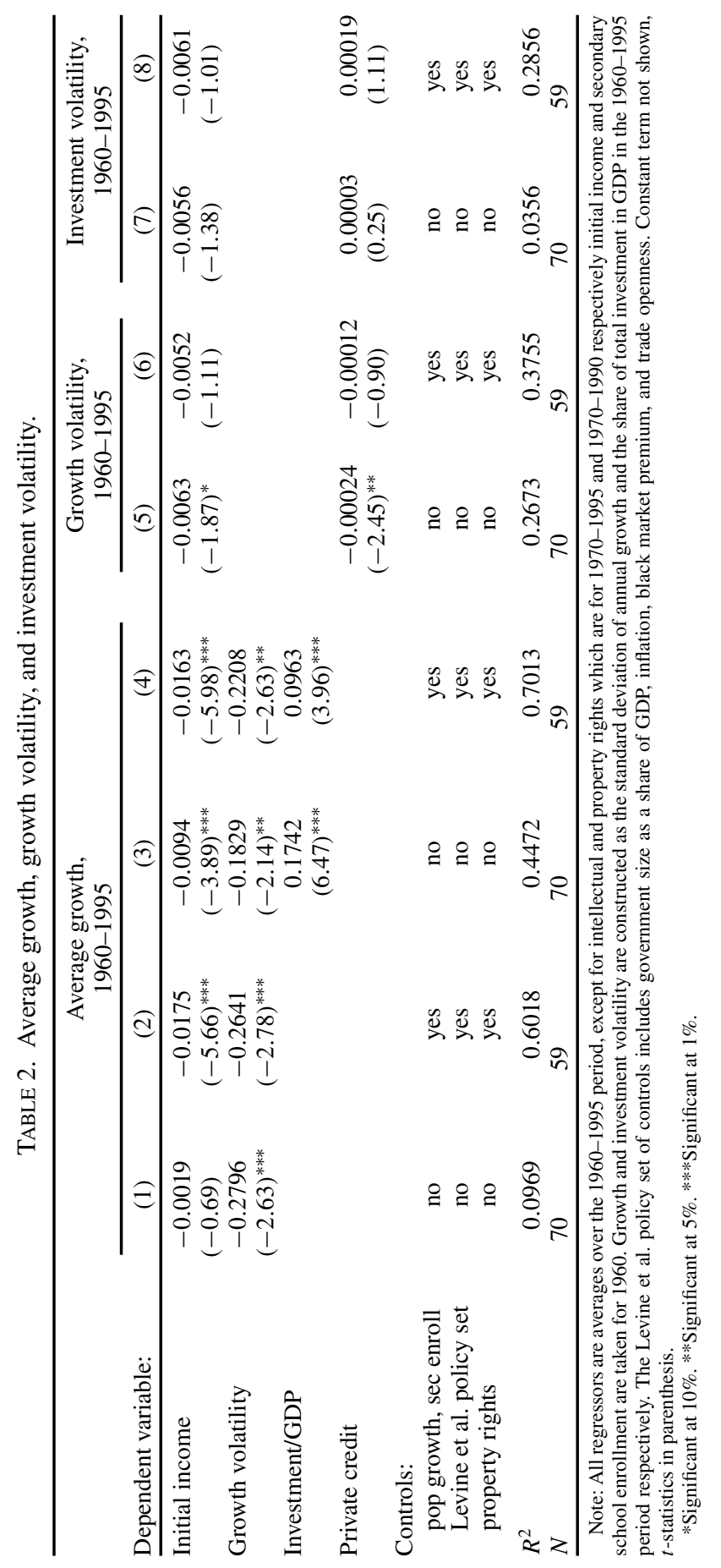


Innovating requires that firms survive short-run liquidity shocks $(R \& D$ is a long-term investment) and that to cover liquidity costs firms can rely only on their short-run earnings plus borrowing. Suppose in addition that growth is driven by innovations, with the growth rate of knowledge (or average productivity) being proportional to the flow of innovating firms in the economy. Absent credit constraints, and provided the value of innovation is sufficiently high, volatility will not affect innovation and growth as firms can always borrow up to the net present value of their future earnings in order to cover the short-run liquidity costs. But, now, suppose that the borrowing capacity of firms is proportional to their current earnings (the factor of proportionality is what we refer to as the credit multiplier, with a higher multiplier reflecting a higher degree of financial development in the economy). In a recession, current earnings are reduced, and therefore so is the firms' ability to borrow in order to innovate. This, in turn implies that the lower financial development, the more the anticipation of recessions will discourage R\&D investments if those are decided before firms know the realization of the aggregate shock ${ }^{19}$ (because firms anticipate that with higher probability, their R\&D investment will not pay out in the long-run as it will not survive the liquidity shock).

More formally, suppose that the liquidity shock $\tilde{c}$ is idiosyncratic across firms, but i.i.d distributed with cumulative distribution function (c.d.f.) $F$, and that the aggregate shock $a_{t}$ over time is distributed according to

$$
a_{t}=\bar{a}+\varepsilon_{t},
$$

where $\rho<1$ and $\varepsilon_{t}$ is i.i.d over time and normally distributed with mean zero and variance $\sigma^{2}$.

Firms live for two periods; at the beginning of the first period, say period $t$, they decide about how to allocate their initial wealth between: (i) short-run capital investment $k_{t}$, which yields short run profit $a\left(k_{t}\right)^{\alpha}$ at the end of the first period; and (ii) long-term R\&D investment $z_{t}$, which yields an innovation value $v_{t+1}$ equal to the expected productivity $E\left(a_{t+1}\right)$ in period $(t+1)$ with probability $q\left(z_{t}\right)=z_{t}^{\alpha}$ in the second period provided the firm overcomes potential liquidity shocks that may occur at the end of their first period. The investment decision is made before the realization of the aggregate shock $a_{t}$. Credit market imperfections prevent a firm with short-run profit flow $a\left(k_{t}\right)^{\alpha}$ to invest more than $\mu a\left(k_{t}\right)^{\alpha}$ for the purpose of covering its idiosyncratic liquidity $\operatorname{cost} \tilde{c}$.

19. See AABM (2005) for the case where investment composition is decided after the realization of the aggregate shock $a_{t}$ 
Because firms choose the allocation of investment before they learn the realization of $a_{t}$, they choose $k$ and $z$ to

$$
\begin{aligned}
& \max _{k, z}\left\{\mathbb{E}_{t}\left(a_{t}\right)\left(k_{t}\right)^{\alpha}+\mathbb{E}_{t}\left(a_{t+1}\right)\left(z_{t}\right)^{\alpha} \mathbb{E}_{t}\left(F\left(\mu a_{t}\left(k_{t}\right)^{\alpha}\right)\right\}\right. \\
& \text { such that } \quad k_{t}+z_{t} \leq \mu w,
\end{aligned}
$$

where $\mathbb{E}_{t}$ refers to the expected value at date $t$, and where we assume that

$$
\mathbb{E}_{t}\left(a_{t}\right)=\mathbb{E}_{t}\left(a_{t+1}\right)=\bar{a} .
$$

Assuming that the c.d.f for the liquidity shock, $F$, is concave, it is immediate to see that a mean-preserving spread of $a_{t}$ will reduce the firm's incentive to invest in $\mathrm{R} \& \mathrm{D}$ and it will also reduce the expected probability of overcoming the liquidity shock, $\mathbb{E}_{t}\left(F\left(\mu a_{t}\left(k_{t}\right)^{\alpha}\right)\right.$. It will thus reduce even more the expected growth rate equal to

$$
g_{t}=\left(z_{t}\right)^{\alpha} \mathbb{E}_{t}\left(F\left(\mu a_{t}\left(k_{t}\right)^{\alpha}\right) .\right.
$$

Based on cross-country panel data over the period 1960-2000, AABM show that the interaction term between financial development and volatility is indeed significantly positive. In theory, one could imagine a counteracting effect of volatility on growth, namely that higher volatility also means higher profits in booms, and therefore a possibly higher ability for firms to innovate during booms; however, the regressions in AABM, Ramey and Ramey (1995), or in Section 5.3, all suggest that this latter effect is of second order.

\subsection{The Effects of Countercyclical Macropolicies on Growth}

Having shown that macroeconomic volatility tends to be more harmful to growth the lower the level of financial development, a natural conjecture is that the tighter the credit constraints faced by firms, the greater the scope for appropriate government intervention in particular to reduce the costs that negative liquidity shocks impose on credit-constrained firms. That government intervention might increase aggregate efficiency in an economy subject to credit constraints and aggregate shocks has already been pointed for example by Holmstrom and Tirole (1998). However, this point has never been formally made in the context of a growth model, nor have its potential empirical and policy implications been explored so far. This section reports a first attempt ${ }^{20}$ at filling this gap, more precisely by

20. The material in this section is drawn from current work by Aghion, Barro, and Marinescu, on cyclical budgetary policies and productivity growth.

$$
\text { “zwu002060318” — 2006/6/27 — page } 304 \text { — \#36 }
$$


analyzing the interplay between financial development and the growth effects of different types of cyclical macropolicies.

To the extent that, in an economy with tight credit constraints, the occurrence of a recession forces a number of firms to cut on innovative investments in order to survive idiosyncratic liquidity shocks, a natural idea is that a countercyclical budgetary may foster innovation and growth by reducing the negative consequences of a recession (or a bad aggregate shock) on firms' innovative investments. For example, the government may decide to increase the volume of its public investments, thereby fostering the demand for private firms' products. Or the government may choose to directly increase its subsidies to private enterprises, thereby increasing their liquidity holdings and thus making it easier for them to face idiosyncratic liquidity shocks without having to sacrifice $R \& D$ or other types of longer-term growth-enhancing investments. From our analysis in the previous section, a natural prediction is that the lower the level of financial development, that is, the tighter the credit constraints faced by firms, the more growth-enhancing such countercyclical policies should be.

Current work by Aghion, Barro and Marinescu (henceforth ABM), analyzes the effects of (counter)cyclical budgetary policies on growth, using annual panel data on 17 OECD countries over the period 1965-2001; in particular, they restrict their analysis to a subset of "reasonable" countries for which Easterly (forthcomming) would predict no effect of policy! Then, ABM perform two-stage least-square regressions where:

1. The first stage regressions estimate, for each year, the correlations between: (i) on the left-hand side of the first-stage equation, variables such as: government debt, primary budget deficit, government investment, government consumption, defense spending, social security spending, direct subsidies to private enterprises; (ii) on the right-hand side of the first-stage equation: (a) the current output gap (measured by the difference between the real GDP and the maximum potential GDP, that is the GDP at minimum level of non-inflationary employment for given capital stock; (b) the current gap in government expenditures (measured by the deviation of government expenditure to its trend); and (iii) the lagged public debt to GDP ratio (which reflects the share of public spending used to meet the outstanding public debt obligations).

Figure 2 summarizes the results from the first-stage regressions with the primary budget deficit as the left-hand-side variable for UK and France; on average over the period, the UK show a much higher degree of councercyclicality of its budget deficit than France does.

2. The second stage regressions estimate, the annual growth rate of per capita GDP (left-hand side variable) as a function of: (i) the lagged value of the cyclicality coefficient obtained from the first stage regression, which we denote by $l c y c l$; (ii) lagged financial development, $l p c$, which we measure once again 


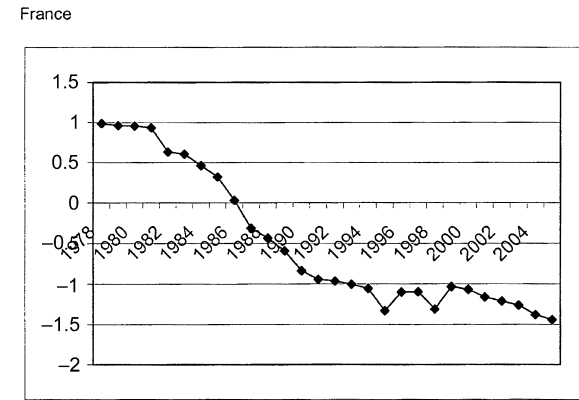

UK

FIGURE 2. Results from first-stage regressions for UK and France.

by the ratio of private credit to GDP; and (iii) the interaction $l c y c l \_l p c$ between these two variables. Our prediction is that the coefficient on $l c y c l$ should be negative (a procyclical budgetary policy is bad for growth in a country with no credit at all) whereas the interaction coefficient on $l c y c l$ lpc should be positive (a procyclical budgetary policy is less detrimental to growth, the higher the level of financial development).

The second-stage results with regard to the primary deficit show that a more procyclical primary deficit is detrimental to growth (the coefficient on lcycl is negative equal to -0.008 if we consider the whole sample of countries, and to -0.015 if we restrict the analysis to countries where the variance in the $c y c l$ coefficient in a VC estimation for the first-stage, is non-zero.

Having shown that countercyclical budget deficits can be growth-enhancing, the next step is to look at the composition of public spending. ABM consider the following categories of spending: (i) public investment; (ii) defense spending, which is part of (i); (iii) direct subsidies to private enterprises; (iv) government consumption; and (v) social security. For each category, ABM perform first-stage regressions of the corresponding variable on the output gap for each country, which yields the corresponding cyclicality coefficient. Then in the second-stage regression, productivity growth is regressed over that coefficient, financial development, and the interaction between the two, controlling for country, or year fixed effects, or both.

Here we shall only show the tables for public investment and government consumption, as the difference between the two is striking. On the one hand, as shown in Table 3, countercyclical public investments are highly growth-enhancing at low levels of financial development with highly negative and significant correlations between productivity growth and the lagged cyclicality of public investment (negative coefficients which are significant at the 5\% both, in the regression controlling for the linear time trend or that controlling for year fixed effects), whereas the interaction coefficients are positive and significant at the $5 \%$ or $1 \%$ when controlling for year fixed effects. 
TABLE 3. Public investment.

\begin{tabular}{|c|c|c|c|}
\hline & \multicolumn{3}{|c|}{ Growth of GDP per capita } \\
\hline & No year effects & Linear time trend & Year fixed effects \\
\hline $\begin{array}{l}\mathrm{Lag}(\text { procyclicality of public } \\
\text { investment) }\end{array}$ & $\begin{array}{r}-0.082 \\
(0.054)\end{array}$ & $\begin{array}{r}-0.077 \\
(0.054)\end{array}$ & $\begin{array}{l}-0.072 \\
(0.035)^{* *}\end{array}$ \\
\hline Lag(private credit/GDP) & $\begin{array}{l}-0.013 \\
(0.007)^{*}\end{array}$ & $\begin{array}{l}-0.015 \\
(0.007)^{* *}\end{array}$ & $\begin{array}{l}-0.012 \\
(0.005)^{* *}\end{array}$ \\
\hline $\begin{array}{l}\text { Lag(procyclicality of public } \\
\text { investment }{ }^{*} \text { private credit/GDP) }\end{array}$ & $\begin{array}{l}0.071 \\
(0.034)^{* *}\end{array}$ & $\begin{array}{l}0.080 \\
(0.034)^{* *}\end{array}$ & $\begin{array}{l}0.082 \\
(0.025)^{* * *}\end{array}$ \\
\hline Relative GDP per capita & $\begin{array}{c}0.001 \\
(0.004)\end{array}$ & $\begin{array}{l}0.032 \\
(0.013)^{* *}\end{array}$ & $\begin{array}{l}0.038 \\
(0.021)^{*}\end{array}$ \\
\hline Year & & $\begin{array}{l}0.001 \\
(0.001)^{* *}\end{array}$ & \\
\hline Constant & $\begin{array}{l}0.039 \\
(0.017)^{* *}\end{array}$ & $\begin{array}{l}-2.441 \\
(0.973)^{* *}\end{array}$ & $\begin{array}{l}0.225 \\
(0.115)^{*}\end{array}$ \\
\hline Observations & 453 & 453 & 453 \\
\hline$R^{2}$ & 0.06 & 0.07 & 0.42 \\
\hline
\end{tabular}

On the other hand, when we turn to government consumption in Table 4, everything becomes insignificant.

Looking at the other components of government spending, ABM find: (a) that countercyclical defense spending is growth-enhancing at low levels of financial development (negative significant direct coefficient with or without year fixed effect or linear time trends) but the interaction coefficient is never significant;

TABLE 4. Government consumption.

\begin{tabular}{lccc}
\hline & \multicolumn{3}{c}{ Growth of GDP per capita } \\
\cline { 2 - 4 } & No year effects & Linear time trend & Year fixed effects \\
\hline Lag(procyclicality of & -0.005 & -0.005 & 0.007 \\
government consumption) & $(0.028)$ & $(0.027)$ & $(0.021)$ \\
Lag(private credit/GDP) & -0.006 & -0.008 & -0.006 \\
& $(0.008)$ & $(0.008)$ & $(0.006)$ \\
Lag(procyclicality of & -0.008 & -0.007 & -0.004 \\
government consumption & & & \\
* private credit/GDP) & $(0.032)$ & $(0.032)$ & $(0.023)$ \\
Relative GDP per capita & 0.002 & 0.028 & 0.028 \\
& $(0.004)$ & $(0.013)^{* *}$ & $(0.022)$ \\
Year & & 0.001 & \\
& & $(0.001)^{* *}$ & 0.168 \\
Constant & 0.037 & -2.101 & $(0.116)$ \\
& $(0.017)^{* *}$ & $(1.000)^{* *}$ & 453 \\
Observations & 453 & 453 & 0.41 \\
$R^{2}$ & 0.05 & 0.06 &
\end{tabular}

Note: All regressions include country fixed effects.

Robust standard errors in parentheses.

*Significant at $10 \%$.**Significant at $5 \%$. ***Significant at $1 \%$. 
TABLE 5. Money supply (M2/GDP).

\begin{tabular}{lccc}
\hline & \multicolumn{3}{c}{ Growth of GDP per capita } \\
\cline { 2 - 4 } & Countiy fixed effects & Year fixed effects & Country and year fixed effects \\
\hline Lag(procyclicality of & 0.001 & -0.005 & -0.003 \\
M2/GPD) & $(0.004)$ & $(0.003)^{*}$ & $(0.004)$ \\
Lag(private credit/GDP) & -0.006 & -0.002 & -0.008 \\
& $(0.007)$ & $(0.002)$ & $(0.006)$ \\
Lag(procyclicality of & 0.001 & 0.007 & 0.005 \\
M2/GDP & & & \\
* private credit/GDP) & $(0.004)$ & $(0.002)^{* * *}$ & $(0.003)$ \\
Relative GDP per capita & 0.003 & 0.001 & 0.029 \\
& $(0.005)$ & $(0.001)$ & $(0.019)$ \\
Constant & 0.038 & 0.028 & 0.172 \\
& $(0.019)^{* *}$ & $(0.004)^{* * *}$ & $(0.099)^{*}$ \\
Observations & 458 & 458 & 458 \\
$R^{2}$ & 0.06 & 0.37 & 0.41 \\
\hline Note: Robust standard errors in parentheses. & & \\
$*$ Significant at 10\%. * Significant at 5\%.** Significant at $1 \%$. &
\end{tabular}

(b) that the coefficients for social security are insignificant (apart from the interaction coefficient in the regression with year fixed effects, which is significant at the 10\%); and (c) that the direct and interaction coefficients for direct subsidies to private enterprises are highly significant in the regression controlling for year fixed effects, still significant in the regression not controlling for year fixed effects or linear time trend, but not significant in the regression controlling for linear time trend only. All these regressions control for country fixed effects.

So far, we have concentrated on budgetary policy. But one could as well perform similar exercises with variables such as the M2/GDP ratio also used by Easterly (2005) or short-term real interest rates which are also linked to monetary policy. For the purpose of this lecture, we have looked at the former, and the second-stage regression is summarized in Table 5.

Unlike for budgetary variables, the coefficients are not very significant except in the regression where one controls for linear time trends; the regression where one controls for year fixed effects shows an interaction coefficient which is significant at the $15 \%$. Thus there is something to having a countercyclical M2/GDP ratio at lower levels of financial development, but nothing as significant as the effect of countercyclical government investment for example.

Finally, what can we say about the interplay between countercyclical budgetary policies and structural reforms such as product or labor market liberalization which we analyzed separately in Section 3? Table 6 shows that the two are complementary: Namely, a higher degree of product or labor market liberalization increases the positive growth impact of countercyclical budgetary policy. A plausible explanation for such complementarity is that government support during a recession, is useful only to the extent that it helps firms maintain long-term innovative investments aimed at entering a new market or a new 
TABLE 6. Product market liberalization.

\begin{tabular}{lcc}
\hline & \multicolumn{2}{c}{ Growth of GDP per capita } \\
\cline { 2 - 3 } & Year fixed effects & Country and year fixed effects \\
\hline Procyclicality of & -0.048 & -0.033 \\
public investment & $(0.025)^{*}$ & $(0.047)$ \\
Product market & -0.011 & 0.002 \\
liberalization & $(0.008)$ & $(0.019)$ \\
Procyclicality of & 0.126 & 0.134 \\
public investment *product & & \\
market liberalization & $(0.057)^{* *}$ & $(0.077)^{*}$ \\
Constant & 0.024 & 0.035 \\
& $(0.003)^{* * *}$ & $(0.008)^{* * *}$ \\
Observations & 352 & 352 \\
$R^{2}$ & 0.33 & 0.39 \\
\hline
\end{tabular}

Note: Robust standard errors in parentheses.

*Significant at $10 \%$.**Significant at $5 \%$.***Significant at $1 \%$.

activity or at improving management methods. However, high entry costs or high labor mobility costs will reduce firms' ability to enter those new activities or to hire employees for the new tasks, with or without government support. This finding goes counter to a common view whereby the implementation of structural reforms would reduce the need for pro-active macroeconomic policies to enhance growth.

\subsection{Back to Europe versus the US}

A natural conclusion from the analysis in this section is that Europe should have budgetary (and to a lesser extent, monetary) policies that are more countercyclical, or at least as much countercyclical, than that in the US given that the US are more financially developed than the EU. Indeed, the ratio of private credit to GDP in the EU is equal 0.76 against 1.32 in the US, and this difference abstracts from differences in stock market and venture capital market development, both markets are also far more developed in the US than in the EU. However, as argued by Aghion, Cohen, and Pisani-Ferry (2005), both the structural deficit and the real interest rates vary much less over time in the Eurozone than in the US. Our analysis suggests that the absence of an active (or reactive) macropolicy in the Eurozone is a potential source of growth deficit in this region.

\section{Conclusion}

In this lecture, we have argued that the Schumpeterian paradigm provides a unifying framework for thinking about and designing appropriate (contextdependent) growth policy. In particular, the paradigm produces precise testable 
predictions as to how growth-maximizing policies (e.g., competition and entry policies, the allocation of education funding, or the design of macroeconomic policies) should vary with a country's or sector's distance to the technological frontier, and/or with the country's level of financial development.

The empirical support we have presented for these predictions implies that policy does indeed matter for a country's growth performance even if, as Easterly (forthcomming) has argued, no linear relationship between policy and growth can be found in the data once institutions are controlled for. This is because appropriate growth policies vary with a country's institutions. For example, the results reported in Section 5.3 imply that countercyclical macro policy promotes growth, but mainly in countries with relatively low financial development. Such effects can be detected only by taking into account the nonlinear interactions predicted by Schumpeterian theory.

We have also emphasized that the separation between (short-run) macroeconomic policy and long-run growth, often assumed in macro textbooks or in policy circles, is theoretically questionable and at odds with cross-country panel regressions; not only does long-run growth respond to fiscal or monetary policy over the cycle, but in addition there is complementarity between the growth effects of a more countercyclical budgetary policy and those of structural reforms such as product market or labor market liberalization.

When comparing the Schumpeterian paradigm to the AK or product diversity models of endogenous growth, we have concluded that the former does a better job at delivering systematic and yet context-dependent policy prescriptions. In particular, the AK model has nothing to say on competition policy, or on how the composition of education spending can affect growth depending on distance to the frontier, and also it fails to capture the interplay between volatility and growth and therefore the potential role for countercyclical macroeconomic policies. The product variety model is bound to remain counterfactual with regard to the effects of competition or firm exit on growth, and because it does not capture the notion of distance to the technological frontier it does not generate appropriate policy prescriptions in areas like competition/entry or education.

The limitations of AK or neoclassical growth models in generating policy prescriptions does not imply however that capital accumulation is unimportant for growth. On the contrary, in Aghion and Howitt (1998, ch. 3) we demonstrated a complementarity between savings and capital accumulation on the one hand and growth-enhancing innovation on the other. ${ }^{21}$ We also believe that the Schumpeterian paradigm can suggest savings and capital accumulation policies that are

21. A higher savings rate leads to a higher steady-state level of capital per efficiency unit of labor, which in turn increases the profit flow accruing to a successful innovator. This in turn results in higher innovation incentives and therefore a higher long-run growth rate. 
context dependent in a way consistent with the data, and can thereby do better than AK on its own territory.

The particular story we have in mind is the following. Catching up with the technological frontier requires a country to attract "know-how," or technological spillovers, from frontier firms in more developed countries. Important vehicles for transferring know-how are foreign direct investment and collaborative ventures between local producers and frontier buyers. However, investment by frontier firms in less developed countries requires a good local investment climate, in the form of macroeconomic stability, social peace, adequate infrastructure, and so on. The problem then is one of commitment on the local government's part to creating such a climate. This in turn requires (private and/or public) savings. For a country close to the frontier, implementation of frontier technologies is less important for growth, and therefore savings should also be less important for growth. For a country very far below the frontier, the fixed costs of setting up the appropriate economic environment may not be affordable at any savings rate, and typically institutions are so bad that they override any potential effect of savings, so we should again observe a low correlation between the savings rate and the growth rate.

A preliminary look at cross-country data confirms this bell-shaped pattern. More specifically, using data from the Penn World Tables on 95 countries between 1960 and 2000, we estimated the equation

$$
g_{i}=\alpha+\beta s_{i},
$$

where $g_{i}$ is country $i$ 's average growth rate of per capita GDP over the sample period and $s_{i}$ is the country's average saving rate (total saving over GDP). The OLS estimate of $\beta$, the effect of saving on growth, was highly significant when we used the whole sample; but when we divided countries into three equal-sized groups depending on distance to the frontier and ran the regression on each group separately, the estimated effect was significant in the middle group but not in the group closest to or furthest from the frontier. ${ }^{22}$

Thus, if saving matters for productivity growth it does so in a way consistent with the idea that implementation becomes less important relative to innovation as a country gets closer to the technological frontier. The interaction effect is predicted by the Schumpeterian paradigm but could not be easily predicted by the AK or product variety model. We believe that this new way of looking at saving may be useful for the design of growth-enhancing policies in middle-income countries, for example those in Latin America, where savings (particularly public savings) are low compared to their Asian counterparts. We leave this and many other open questions on appropriate growth policy for future research.

22. Distance was measured by the sample average value of per-capita GDP. Using the full sample the estimated value of $\beta$ was 0.05 with a $t$-statistic of 5.08, using the middle group it was 0.07 with $t=3.04$, using the group closest to the frontier it was 0.04 with $t=1.38$, and using the group furthest from the frontier it was 0.01 with $t=0.44$. 


\section{References}

Acemoglu, Daron, Philippe Aghion, and Fabrizio Zilibotti (2002). "Distance to Frontier, Selection, and Economic Growth.” NBER Working Paper No. 9066.

Acemoglu, Daron, and Jaume Ventura (2002). "The World Income Distribution." Quarterly Journal of Economics, 117, 659-694.

Aghion, Philippe, Marios Angeletos, Abhijit Banerjee, and Kalina Manova (2005). "Volatility and Growth: Credit Constraints and Productivity-Enhancing Investment." Working paper, Harvard-MIT.

Aghion, Philippe, Nick Bloom, Richard Blundell, Rachel Griffith, and Peter Howitt (2005). "Competition and Innovation: An Inverted-U Relationship." Quarterly Journal of Economics, 120, 701-728.

Aghion, Philippe, Richard Blundell, Rachel Griffith, Peter Howitt, and Susanne Prantl (2004). "Entry and Productivity Growth: Evidence from Micro-Level Panel Data." Journal of the European Economic Association, Papers and Proceedings, 2, 265-276.

Aghion, Philippe, Richard Blundell, Rachel Griffith, Peter Howitt, and Susanne Prantl (2005). "The Effects of Entry on Incumbent Innovation and Productivity." Working paper, HarvardUCL.

Aghion, Philippe, Leah Boustan, Caroline Hoxby, and Jerome Vandenbussche (2005). "Exploiting States' Mistakes to Evaluate the Impact of Higher Education on Growth.” Working paper, Harvard.

Aghion, Philippe, Robin Burgess, Stephen Redding, and Fabrizio Zilibotti (2005a). "Entry Liberalization and Inequality in Industrial Performance." Journal of the European Economic Association, Papers and Proceedings

Aghion, Philippe, Robin Burgess, Stephen Redding, and Fabrizio Zilibotti (2005b). "On the Unequal Effects of Liberalization: Theory and Evidence from Indian Delicensing Data." Working paper, LSE-Harvard-IIES.

Aghion, Philippe, Elie Cohen, and Jean Pisani-Ferry (2005). Politique Economique et Croissance en Europe. La Documentation Francaise.

Aghion, Philippe, and Peter Howitt (1992). "A Model of Growth through Creative Destruction." Econometrica, 60, 323-351.

Aghion, Philippe, and Peter Howitt (1998). Endogenous Growth Theory, MIT Press.

Aghion, Philippe, Peter Howitt, and David Mayer-Foulkes (2005). "The Effect of Financial Development on Convergence: Theory and Evidence." Quarterly Journal of Economics, 120, 173-222.

Barro, Robert, and Jong-Wha Lee (2000). "International Data on Educational Attainment: Updates and Implications." Working Paper No. 42, Center for International Development at Harvard University.

Benhabib, Jess, and Mark Spiegel (1994). "The Role of Human Capital in Economic Development: Evidence from Aggregate Cross-Country Data.” Journal of Monetary Economics, 34, 143-173.

Bils, Mark, and Peter Klenow (2000). "Does Schooling Cause Growth?” American Economic Review, 90, 1160-1183.

Blundell, Richard, Rachel Griffith, and John Van Reenen (1995). "Dynamic Count Data Models of Technological Innovation." Economic Journal, 105, 333-344.

Comin, Diego, and Sunil Mulani (2005). "A Theory of Growth and Volatility at the Aggregate and Firm Level." Working paper, New York University.

Dixit, Avinash, and Joseph Stiglitz (1977). "Monopolistic Competition and Optimum Product Diversity." American Economic Review, 67, 297-308.

Easterly, William (2001). The Elusive Quest for Growth: Economists' Adventures and Misadventures in the Tropics. MIT Press. 
Easterly, William (2001). "National Policies and Economic Growth: A Reappraisal." In Handbook of Economic Growth, edited by P. Aghion and S. Durlauf, Elsevier.

Fogel, Kathy, Randall Morck, and Bernard Yeung (2005). "Corporate Stability and Economic Growth: Is What's Good for General Motors Good for America?” Working paper, University of Alberta.

Frankel, Marvin (1962). "The Production Function in Allocation and Growth: A Synthesis." American Economic Review, 52, 995-1022.

Gerschenkron, Alexander (1962). Economic Backwardness in Historical Perspective. Harvard University Press.

Ha, Joonkyung, and Peter Howitt (2005). "Accounting for Trends in Productivity and R\&D: A Schumpeterian Critique of Semi-Endogenous Growth Theory." Working paper, Brown University.

Helpman, Elhanan (1993). "Innovation, Imitation, and Intellectual Property Rights." Econometrica, 61, 1247-1280.

Holmstrom, Bengt, and Jean Tirole (1998). "Private and Public Supply of Liquidity." Journal of Political Economy, 106, 1-40.

Howitt, Peter (2000). "Endogenous Growth and Cross-Country Income Differences." American Economic Review, 90, 829-846.

Howitt, Peter, and David Mayer-Foulkes (2005). "R\&D, Implementation and Stagnation: A Schumpeterian Theory of Convergence Clubs." Journal of Money, Credit and Banking, 37, 147-177.

Jones, Charles (1995). "R\&D-Based Models of Economic Growth.” Journal of Political Economy, 103, 759-784.

Jones, Larry, Rodolfo Manuelli, and Ennio Stacchetti (2001). "Technology and Policy Shocks in Models of Endogenous Growth." Working Paper No. 281, Federal Reserve Bank of Minneapolis.

King, Robert, and Sergio Rebelo (1993). "Transitional Dynamics and Economic Growth in the Neoclassical Model." American Economic Review, 83, 908-931.

Krebs, Tom (2003). "Human Capital Risk and Economic Growth." Quarterly Journal of Economics, 118, 709-44.

Krueger, Alan, and Mikael Lindahl (2001). "Education for Growth: Why and For Whom?" Journal of Economic Literature, 39, 1101-1136.

Levine, Ross, Norman Loayza, and Thorsten Beck (2000). "Financial Intermediation and Growth: Causality and Causes." Journal of Monetary Economics, 46, 31-77.

Lucas, Robert (1988). "On the Mechanics of Economic Development." Journal of Monetary Economics, 22, 3-42.

Mankiw, Gregory, David Romer, and David Weil (1992). "A Contribution to the Empirics of Economic Growth." Quarterly Journal of Economics, 25, 275-310.

Nelson, Richard, and Edmund Phelps (1966). "Investment in Humans, Technological Diffusion, and Economic Growth." American Economic Review, Papers and Proceedings, 61, 69-75.

Nickell, Steven (1996). "Competition and Corporate Performance." Journal of Political Economy, 104, 724-746.

Nicoletti, Giuseppe, and Stefano Scarpetta (2003). "Regulation, Productivity and Growth." Economic Policy, 36, 11-72.

Ramey, Garey, and Valerie Ramey (1995). "Cross-Country Evidence on the Link between Volatility and Growth." American Economic Review, 85, 1138-1151.

Rodrik, Dani (forthcoming). "Growth Strategies." In Handbook of Economic Growth, edited by P. Aghion and S. Durlauf, Elsevier.

Romer, Paul (1986). "Increasing Returns and Long-Run Growth.” Journal of Political Economy, 94, 1002-1037.

Romer, Paul (1990). "Endogenous Technical Change.” Journal of Political Economy, 98, 71-102. 
Sapir, Andre, et al. (2003). An Agenda for A Growing Europe. Oxford University Press.

Schumpeter, Joseph (1934). The Theory of Economic Development. Harvard University Press. Stadler, George (1990). "Business Cycles Models with Endogenous Technology." American Economic Review, 80, 763-778.

Uzawa, Hoshi (1965). "Optimum Technical Change in an Aggregative Model of Economic Growth." International Economic Review, 6, 18-31.

Vandenbussche, Jerome, Philippe Aghion, and Costas Meghir (2004). "Growth, Distance to Frontier and the Composition of Human Capital.” Working paper, Harvard-UCL. 